2013

\title{
Understanding Curtiss-Wright
}

Edward A. Purcell Jr.

New York Law School

Follow this and additional works at: http://digitalcommons.nyls.edu/fac_articles_chapters

\section{Recommended Citation}

31 Law \& Hist. Rev. 653 (2013)

This Article is brought to you for free and open access by the Faculty Scholarship at DigitalCommons@NYLS. It has been accepted for inclusion in Articles \& Chapters by an authorized administrator of DigitalCommons@NYLS. 


\title{
Understanding Curtiss-Wright
}

\author{
EDWARD A. PURCELL JR.
}

The most striking feature of the Supreme Court's decision in United States v. Curtiss-Wright Export Corp. is its language asserting an independent and exclusive executive foreign affairs power. As "the sole organ of the federal government in the field of foreign relations," the Court declared, the executive holds "very delicate, plenary and exclusive power" that "does not require as a basis for its exercise an act of Congress." From the day the case was decided, it has stood as a preeminent authority for those who would magnify the constitutional role of the president by proclaiming the independent and unchecked nature of the executive's foreign affairs power. ${ }^{2}$

1. United States v. Curtiss-Wright Export Corp., 299 U.S. 304, 320 (1936).

2. The idea of "unchecked executive discretion" in foreign affairs "did not fully and officially crystallize until Justice George Sutherland's controversial, oft-cited 1936 opinion for the Court in United States v. Curtiss-Wright Export Corp." Harold Hongju Koh, The National Security Constitution: Sharing Power after the Iran-Contra Affair (New Haven:

Edward A. Purcell, Jr., is Joseph Solomon Distinguished Professor at New York Law School<epurcell@nyls.edu>. He thanks Richard B. Bernstein, Steven J. Ellmann, Daniel R. Ernst, Barry Friedman, Richard D. Friedman, Helen Hershkoff, Andrew L. Kaufman, Ann Kornhauser, Richard A. Matasar, William E. Nelson, Robert Post, Mark Tushnet, Melvin I. Urofsky, Rachel Vorspan, the members of the New York University Law School Legal History Colloquium, his colleagues in the New York Law School Faculty Colloquium, and four anonymous reviewers for this journal for their many helpful comments and suggestions. He also thanks Matthew Hofstedt of the Collection of the Supreme Court, Office of the Curator, and Michael McCarthy of New York Law School for their help in obtaining source material, and New York Law School students Melissa Baldwin, Alex Barrett, Andrew Finan, Daniel Luisi, Sophie Reiter, and John B. Weinstein for their research assistance. 
Because Curtiss-Wright's executive power language has been so frequently cited-and so frequently challenged-this article seeks a fuller understanding of the case and its constitutional significance by seeking to answer two basic historical questions: Where did the language about "plenary and exclusive" executive power come from, and why did the Court adopt it? The conventional explanation is that Justice George Sutherland, the opinion's author, persuaded the Court to accept his own long-held theory of constitutional foreign affairs powers, and that he was responsible for the opinion's content. "Sutherland's success in winning the Court to his view of the foreign relations power," his biographer proudly proclaimed, "was a personal triumph of proportions seldom encountered in judicial biography."

This article challenges both the claim that the "plenary and exclusive" executive power language was Sutherland's and the claim that the views he expressed about that power had been "long-held," and it offers a more complex and revealing explanation of the origin, adoption, and significance of that language. Placing this somewhat unusual, and in several ways puzzling, case in the historical context of the mid-1930s and examining the interacting ideas, attitudes, and policy goals of the individual justices, it marshals the available historical evidence to support three general claims. ${ }^{4}$

Yale University Press, 1990), 72 (emphasis in original). Accord Hadley Arkes, The Return of George Sutherland: Restoring a Jurisprudence of Natural Rights (Princeton: Princeton University Press, 1994), 34-35 (referring to "Justice Sutherland's doctrines in the Curtiss-Wright case" and "that sobering truth taught by Justice Sutherland: that, in the field of foreign affairs, the president is a source of law"). For a pivotal example of the use of the case, see United States Department of State, "Authority of the President to Repel the Attack in Korea (July 3, 1950)," Department of State Bulletin 23 (1950): 173 (citing Curtiss-Wright for the president's "duty of conducting the foreign relations of the United States," at 174, and arguing for the executive's unilateral authority to commit American troops to the Korean "police action").

3. Joel Francis Paschal, Mr. Justice Sutherland: A Man Against the State (Princeton: Princeton University Press, 1951), 226. See, for example, Arkes, Return of George Sutherland, 174, 197, 219, 237-38, 241, 286-87; Louis Fisher, Constitutional Conflicts Between Congress and the President, 4th ed. (Lawrence, Kansas: The University Press of Kansas, 1997), 95; Charles A. Lofgren, "Government From Reflection and Choice": Constitutional Essays on War, Foreign Relations, and Federalism (New York: Oxford University Press, 1986), 180; G. Edward White, The Constitution and the New Deal (Cambridge, MA: Harvard University Press, 2000), 73; and David Levitan, "The Foreign Relations Power: An Analysis of Mr. Justice Sutherland's Theory," Yale Law Journal 55 (1946): 476.

4. The author is aware of no historical evidence-with a single exception of quite limited content-that records or summarizes the deliberations of the justices in Curtiss-Wright. He has not, for example, been able to locate any memos discussing the case, early drafts of the opinion, or "returns" on circulated drafts. The exception is material in the Collection of the 
First, it argues that the executive power language most likely came not from Sutherland but from Chief Justice Charles Evans Hughes, and that Hughes was the architect of both the Court's 7-1 majority and the opinion's executive power language. Second, it argues that the majority justices, although animated by somewhat varying individual considerations, likely accepted

Supreme Court, Office of the Curator (hereafter CSC), which holds docket books of Justices Brandeis, Butler, Roberts, and Van Devanter that contain entries for Curtiss-Wright. The books of Roberts and Van Devanter unfortunately contain no relevant information, although Roberts's book does record the conference vote. The books of Brandeis and Butler also record the vote and, in addition, contain several brief and often difficult or almost impossible to read entries. Where relevant, the material in the docket books is cited and discussed subsequently. The collection also contains the docket books of Stone and Cardozo, but neither contains an entry for Curtiss-Wright. There are no docket books for the 1936 term for McReynolds, Sutherland, or Hughes, the chief justice apparently having ordered his docket books to be destroyed. The article, therefore, necessarily relies on certain inferences and speculations. A substantial and highly suggestive body of evidence drawn from the justices' biographies, public writings, formal legal opinions, and private communications nonetheless provides an extensive foundation for those inferences. Further, an overwhelming body of scholarship in law, history, and political science has established the fact that Supreme Court justices are influenced in varying degrees and on various issues by both the press of external events and their own values and perceptions. See, for example, Lee Epstein, William M. Landes, and Richard A. Posner, The Behavior of Federal Judges: A Theoretical and Empirical Study of Rational Choice (Cambridge, MA: Harvard University Press, 2013); William M. Landes and Richard A. Posner, "Rational Judicial Behavior: A Statistical Study," Journal of Legal Analysis 1 (2009): 775; Cass A. Sunstein, David Schkade, Lisa M. Ellman, and Adres Sawicki, Are Judges Political? An Empirical Analysis of the Federal Judiciary (Washington, DC: The Brookings Institution, 2006); Lee Epstein and Jack Knight, The Choices Justices Make (Washington, DC: Congressional Quarterly Press, 1998); H.W. Perry Jr., Deciding to Decide: Agenda Setting in the United States Supreme Court (Cambridge, MA: Harvard University Press, 1994); and Jeffrey A. Segal and Harold J. Spaeth, The Supreme Court and the Attitudinal Model Revisited (New York: Cambridge University Press, 2002). Such individual and contextual factors were particularly significant in Curtiss-Wright, the article argues, because the Court's adoption of the "plenary and exclusive" executive power language was neither required by the facts of the case nor compelled by existing legal sources. Indeed, the legal sources the Court relied on in making its assertion about executive power were tangential or irrelevant. See note 22 below. Thus, in the absence of controlling or clearly directive legal sources, the justices in Curtiss-Wright enjoyed a relatively broad discretion in shaping the Court's opinion as they wished. Finally, there is a burgeoning literature on the social and ideological reasons why justices support or oppose exercises of executive power. See, for example, Rob Robinson, "Executive Branch Socialization and Deference on the U.S. Supreme Court," Law \& Society Review 46 (2012): 889-921. This article is generally consistent with this literature in pointing to social and ideological influences on decisions involving executive power, but it also qualifies much of that literature by stressing the importance of quite specific individual and contextual factors. See, for example, Epstein, Landes, and Posner, Behavior of Federal Judges, 386 (judges sometimes motivated by "more personal causes than just trying to apply "the law"'). 
Hughes's views and the executive power language because they agreed upon certain fundamental and highly controversial foreign policy goals. They adopted sweeping but vague executive power language, it maintains, to provide practical support for President Franklin Roosevelt in his contemporaneous struggle with Congress over the nation's foreign policy, especially his efforts to implement an anti-Nazi foreign policy and to secure discretionary authority over arms embargos. Finally, the article concludes that Curtiss-Wright properly has no determinative significance as a legal precedent. The opinion's executive power language was vague and unnecessary, and it did not address any issue involving a constitutional conflict either between Congress and the executive or between governmental power and individual rights. Curtiss-Wright's true constitutional significance, then, lies not in any guiding doctrine it established but in the lessons it teaches about the possibilities inherent in both the Supreme Court as an institution and the Constitution's structure of separated national powers. It shows, that is, the power of social context to shape the Court's work, the critical importance of the specific individuals who occupy its bench and the specific policy judgments they make, and the Court's limited but critical power to intervene when it chooses in controversial political and inter-branch conflicts.

The article proceeds in eight parts. The first explains the background of the case and the Court's decision and opinion, and it shows that Sutherland did not merely "win" the Court to his own long-held views but that he altered those views substantially in order to proclaim the "plenary and exctusive" foreign affairs power of the executive. The second part outlines the foreign policy debates of the mid-1930s and argues that escalating fears over Nazism and an anticipated new world war were necessary, but insufficient, spurs for the Court's decision and opinion. The third part examines the role of Chief Justice Hughes, focusing on his experiences as secretary of state in the 1920 s and the development of his constitutional views on foreign affairs law. It concludes that he was most likely the driving force behind the Court's action and the source of its executive power language. The next two parts then address two particularly puzzling questions about the justices who adopted that language. First, why did Sutherland alter his long-held views on foreign affairs law and embrace the principle - inconsistent with his earlier writings-that the executive held "plenary and exclusive" power in the area. Second, why did Justice Louis Brandeis join an opinion that contradicted his most fundamental jurisprudential principles, both his procedural "avoidance" canon and his substantive views on separation of powers and the necessity of constitutional checks on the executive? The sixth part considers the likely reasons why the other majority justices-Benjamin N. Cardozo, Willis Van Devanter, Pierce 
Butler, and Owen J. Roberts--joined the Court's opinion, and why Justice James C. McReynolds, the opinion's sole dissenter, refused to accept it. The penultimate part examines the position of Justice Harlan F. Stone who was seriously ill and unable to participate in the case but who, upon returning to the bench, immediately disapproved it in the strongest terms. Stone rejected the Court's opinion because he opposed discretionary arms embargo authority for the executive and feared Roosevelt's anti-Nazi foreign policy. His actions, the article argues, lend further support to the claim that the majority acted for its own substantive, but quite contrary, reasons of foreign policy. The last part proposes a historical explanation of the Court's behavior, advances a theory of Curtiss-Wright's true significance, and identifies some lessons the case teaches about the possibilities inherent in Supreme Court decision making and in the Constitution's structure of divided national powers.

\section{Curtiss-Wright}

In 1934, President Franklin D. Roosevelt signed a narrowly tailored joint congressional resolution directed at ending the Chaco War between Paraguay and Bolivia. The resolution authorized the president, under certain conditions, to issue a proclamation making it unlawful to sell arms in the United States to either country, and Roosevelt promptly declared the conditions met and issued the requisite proclamation. Subsequently, the government brought a criminal prosecution against the Curtiss-Wright Export Corporation for violating the proclamation by selling fifteen machine guns to Bolivia. The trial court dismissed the indictment on the ground that the resolution constituted "an invalid delegation of legislative power."5

Congress had been delegating authority to the executive since the $1790 \mathrm{~s}$, and in the late nineteenth century its delegations grew broader and more general. In 1928, Chief Justice William Howard Taft synthesized a diffuse body of precedents and announced a flexible general test: The working relations between the federal branches should be determined in light of "common sense and the inherent necessities of the governmental co-ordination." A delegation was constitutional, then, as long as

5. Curtiss-Wright, 314. In addition to the corporation, there were several individual defendants. For excellent discussions of the case, see H. Jefferson Powell, "The Story of Curtiss-Wright Export Corp.," in Presidential Power Stories, ed. Christopher H. Schroeder and Curtis A. Bradley (New York: Foundation Press, 2009), 195-231; and Robert A. Divine, "The Case of the Smuggled Bombers," in Quarrels That Have Shaped the Constitution, ed. John A. Garraty (New York: Harper \& Row, 1988), 253-65. 
"Congress shall lay down by legislative act an intelligible principle" sufficient to guide the executive's exercise of discretion. ${ }^{6}$

In spite of challenges over the years, the Court had never- until the New Deal-applied the delegation doctrine to void an act of Congress. In 1935, however, it did so twice. In Panama Refining Co. v. Ryan, it struck down a critical section of the New Deal's National Industrial Recovery Act on the ground that it left the president "without standard or rule" to confine his discretion. Then, in Schechter Poultry Corp. v. United States, it invalidated the rest of the act for conferring "virtually unfettered" discretion to enact "laws for the government of trade and industry throughout the country." What the act referred to as a finding of "fact," the Court announced, was "really but a statement of an opinion as to the act's general effect upon the promotion of trade or industry."

Under those two decisions, the congressional resolution in Curtiss-Wright appeared vulnerable. It authorized the president's proclamation if two conditions precedent were met. The first was that "the president finds" that a prohibition on arms sales "may contribute to the reestablishment of peace" between the warring countries. The second was that "after consultation with the governments of other American Republics and with their cooperation, as well as that of such other governments as he may deem necessary, he makes proclamation to that effect." The president's proclamation recited the terms of the resolution and announced that the specified "finding" had been made and that the other requisite actions had taken place. It then declared in force the criminal sanctions that the resolution specifred. ${ }^{8}$

Relying primarily on Schechter, the trial court ruled that Congress had not authorized the president to act on the basis of a "true" finding of "fact." Rather, it authorized the proclamation on the basis of "an opinion or forecast." "Thus, the resolution lacked "an intelligible principle" to which the executive was required to conform and was, consequently, unconstitutional.

On direct appeal to the Supreme Court, the parties concentrated on the delegation issue. The government rejected the trial court's distinction

6. J.W. Hampton, Jr. \& Co. v. United States, 276 U.S. 394, 406, 409 (1928). For an example of an earlier delegation case, see Field v. Clark, 143 U.S. 649, 680, 693 (1892).

7. Panama Refining Co. v. Ryan, 293 U.S. 388, 415, 418 (1935); and Schechter Poultry Corp. v. United States, 295 U.S. 495, 542, 541, 538 (1935).

8. Curtiss-Wright, 312-13. The joint resolution provided for both fines (not exceeding $\$ 10,000$ ) and imprisonment (not exceeding 2 years) for violators. More than two decades earlier, a similar congressional delegation had not raised a constitutional challenge. United States v. Chavez, 228 U.S. 525 (1913).

9. Curtiss-Wright 14 F. Supp. 230, 239 (Southern District of New York. 1936). 
between facts and forecasts, cited numerous cases upholding statutes that delegated authority requiring judgments about future events, and argued that the "only test" of constitutionality was whether a delegation constrained the executive's "free and arbitrary discretion." It did not stress the foreign relations context but emphasized only that facts relating to the sale of arms to a foreign government were "peculiarly available to the President." Responding, defendants countered that the resolution gave the president "unfettered discretion" and pointed out that, regardless of any "findings," it did not require him to take any action whatever. They insisted, moreover, that the delegation doctrine made "no distinction" between congressional acts governing domestic matters and "legislation which may affect our foreign relations."10

Writing for the Court, Sutherland took a radically different path than either the government or the defendants had proposed. Drawing on his extensive pre-Court writings, he began by stressing two broad sovereigntybased principles. First, in "external" affairs - those dealing with foreign relations - the national government was sovereign and, therefore, held complete and exclusive power. Its "external" powers were different from its "internal" powers "both in respect of their origin and their nature." In "internal" matters, the national government shared power with the states, and its powers were delegated and sharply limited; in "external" matters, however, the national government possessed all power, while the states had none. Second, the "external" powers of the national government were not limited to its delegated powers but existed independent of the Constitution "as necessary concomitants of nationality" inherent in the nature of sovereignty under the law of nations. The "investment of the federal government with the powers of external sovereignty," Sutherland declared, "did not depend upon the affirmative grants of the Constitution."11

10. Powell, "Story of Curtiss-Wright," 213-17 (quotes at 214 and 215). The government had a right of direct appeal under the Criminal Appeals Act of March 2, 1907, 34 Stat. 1246, as amended, 18 U.S.C. Sec. 682.

11. Curtiss-Wright, 315, 318. For the discussion of internal and external powers, see ibid,, 315-19. Sutherland's earlier writings appeared as "The Internal and External Powers of the National Government," North American Review 191 (1910): 373-89, reprinted as S. Doc. No. 417, 61 Cong., 2 Sess. (1910) [hereafter cited as "Sen. Doc. 417] and Constitutional Power and World Affairs (New York: Columbia University Press, 1919). In elaborating his sovereignty principles Sutherland drew on a doctrine of "inherent national power" over foreign affairs that had developed in the Court's jurisprudence in the late nineteenth century. That doctrine, however, identified such "inherent" power as a power of "the nation" and of Congress, not of the executive. Sarah H. Cleveland, "Powers Inherent in Sovereignty: Indians, Aliens, Territories, and the Nineteenth-Century Origins of Plenary Power Over Foreign Affairs," Texas Law Review 81 (2002): 1-284; Sarah H. Cleveland, "The Plenary 
Whereas Sutherland's discussion of those two sovereignty-based principles came directly from his earlier writings, his subsequent comments on executive power-and his emphasis on its independence and exclusivity - did not. International relations presented "important, complicated, delicate and manifold problems," he announced, and the president was the dominant authority and "alone has the power to speak or listen as a representative of the nation." The executive "alone" held the power to negotiate treaties, and "Congress itself is powerless to invade it." Any "participation in the exercise of the [executive's] power is significantly limited." Then, turning to the case at hand, he explained that "we are here dealing not alone with an authority vested in the President by an exertion of legislative power, but with such an authority plus the very delicate, plenary and exclusive power of the President as the sole organ of the federal government in the field of international relations." That exclusive executive foreign affairs power, he stressed, "does not require as a basis for its exercise an act of Congress." 12

Sutherland concluded that a different standard applied to delegations in "external" matters. If "serious embarrassment" was to be avoided in "the maintenance of our international relations," Congress "must often accord to the President a degree of discretion and freedom from statutory restriction which would not be admissible were domestic affairs alone involved." Practical considerations, he added, also counseled greater flexibility in foreign affairs, for the executive had "confidential sources of information" and other practical advantages that gave him "the better opportunity of knowing the conditions that prevail in foreign countries, and especially is this true in time of war." 13

Sutherland then sought to provide further support for the congressional resolution by adding an extended discussion of "the unbroken legislative practice" of delegating authority to the executive in conducting the nation's foreign relations. Although such an established practice did not necessarily prove the constitutionality of those delegations, it "must be given unusual weight in the process of reaching a correct determination." The weight of

Power Background of Curtiss-Wright," University of Colorado Law Review 70 (1999): 1126-55.

12. Curtiss-Wright; 319-20. Sutherland added the limiting factor that he had noted in his earlier writings: executive power, "like every other governmental power, must be exercised in subordination to the applicable provisions of the Constitution." Ibid., 320. The Court had long recognized the power of the United States government to control foreign affairs, but it had placed that power in Congress or in a combination of congressional and executive power. See, for example, Mahler v. Eby, 264 U.S. 32, 40 (1924); and Mackenzie v. Hare, 239 U.S. 299 (1915).

13. Curtiss-Wright, 320. 
the practice, he concluded, demonstrated that the delegation at issue in Curtiss-Wright was proper. The "uniform, long-continued and undisputed legislative practice just disclosed rests upon an admissible view of the Constitution" that the Court "should not feel at liberty at this late day to disturb." 14 With that, Sutherland upheld the delegation, sanctioned the government's prosecution, and reversed the judgment below.

Aside from his dubious sovereignty-based principles, two aspects of Sutherland's opinion were especially puzzling. One was that it did not simply track his long-established views on foreign affairs law but revised them in a critical way. In his 1910 article on "The Internal and External Powers of the National Government," he did not distinguish between Congressional and executive powers but maintained only that "external" foreign affairs powers belonged exclusively to the "national" government. In 1919, when he did address the allocation of external powers in his book Constitutional Power and World Affairs, he emphasized that Congress and the executive shared those powers and that their roles were "co-ordinate." Discussing the treaty power in his book, for example, Sutherland gave an equal and comprehensive scope to the authority of the Senate and highlighted its right "to participate in the making of treaties at any stage of the process." In contrast, in Curtiss-Wright he emphasized that the executive "alone" negotiated treaties. "Into the field of negotiation the Senate cannot intrude; and Congress itself is powerless to invade it." Similarly, in 1919, when he discussed the "inherent" and "sovereign" powers of "the general government," he noted repeatedly that it was Congress--not the executive - that exercised those powers. In addressing war powers, for example, he emphasized that the "authority of the President" was "wholly dependent upon the action of Congress," that only Congress could suspend the writ of habeas corpus, and that all domestic arrangements 'considered necessary remained "under the direction of Congress." In contrast, in Curtiss-Wright, he argued that the executive possessed certain inherent foreign affairs powers that were "plenary and exclusive" and that could be exercised free of any need for congressional authorization. ${ }^{15}$

Most arresting was that his book warned against a dangerous growth in the "potency and influence" of the executive, a growth that was "never dreamed of by those who framed and adopted the Constitution." It protested that "Congress has been subjected to such a degree of executive domination as to threaten the stability of the principle of departmental

14. Ibid., 320-29 (quotes at 327 and 329).

15. Sutherland, "Internal and External Powers of the National Government," passim; Sutherland, Constitutional Power, 50-69, 76-78, 91, 99, 110, 122-28; Curtiss-Wright, 319,320 . 
independence involved in the distribution of the several powers among the three branches of government." Fearful that the American people were "coming to regard [the President] as the sole repository of their power," Sutherland repudiated that view. "[V]ery decidedly, he is not." 16 Thus, whereas he drew on his long-held views about sovereignty and the "national" nature of foreign affairs powers in Curtiss-Wright, he also altered those views substantially, expanding the scope of executive power and declaring some of those powers exclusive to the executive and independent of Congress.

The second striking feature of Sutherland's opinion was the unnecessary nature of that language about "plenary and exclusive" executive foreign affairs power. Because Congress had authorized the president's action, there was no need to discuss any such independent or exclusive power. Sutherland could have rested soundly on either of two narrow grounds. First, he could have held that the tightly circumscribed scope of the delegation and its clear and specific purpose brought it within the established "intelligible principle" rule. ${ }^{17}$ Second, he could have relied upon the "uniform, long-continued and undisputed legislative practice" that he discussed at length. His opinion declared that the Court should not declare delegations unconstitutional unless "beyond all rational doubt it finds them to be so" and, further, that the "impressive array of legislation" that the Court had approved over the past century and a half "must be given unusual weight." 18 Under those two combined standards-that unconstitutionality must be clear "beyond all rational doubt" and that prior practice "must be given unusual weight"-Sutherland could easily have held that longaccepted practice constituted a "sufficient warrant" for upholding the delegation.

Why Sutherland disregarded those narrow grounds is a matter of speculation. An almost certain, though only partial, explanation is that the justices were sharply divided on the delegation issue. Cardozo and, to a lesser extent, Brandeis, were opposed to a highly restrictive doctrine as a general matter, while Hughes and Roberts were opposed to a restrictive doctrine in the case at hand. The Court's conservatives, conversely, were determined to enforce a relatively rigid delegation doctrine. Therefore, to secure a healthy majority that bridged divisions among the justices, the Court's opinion needed a broader ground for its decision, and

16. Sutherland, Constitutional Power, 75.

17. J.W. Hampton, 409. The Court had often adopted a flexible approach. Butterfield v. Stranahan, 192 U.S. 470, 496 (1904) (delegations need only be "reasonably practicable" in light of "the necessities of the case").

18. Curtiss-Wright, 327. 
Sutherland's "internal/external" dichotomy served that purpose. It allowed the Court to adopt a relatively loose delegation standard that was acceptable to Hughes, Roberts, Cardozo, and Brandeis, while confining the standard's application to "external" affairs to satisfy Sutherland, Van Devanter, and Butler. ${ }^{19}$

If such a compromise explained both the Court's rejection of the available narrow grounds and its acceptance of Sutherland's broad "internal/ external" dichotomy, it did not explain why the Court also adopted the additional and unnecessary language about "plenary and exclusive" executive power. ${ }^{20}$ Earlier in the year, the Court had twice refused to accept a doctrine of independent executive foreign affairs power. It is most striking that in February a unanimous bench refused to address the scope of independent executive authority in foreign affairs and relied instead upon the fact that the president had acted under the authority of a congressional statute, exactly the situation that Curtiss-Wright presented. ${ }^{21}$

Why, then, did the Court abruptly address the issue that it had avoided earlier in the year? Why did it do so when addressing that issue was unnecessary to its decision? Why did it do so when its executive power language relied on authorities that were thin and tangential, if not simply irrelevant? ${ }^{22}$ Why was Sutherland willing to change his own long-held

19. Ibid., 329. The Court's acceptance of Sutherland's dichotomy was almost certainly critical to bringing the seven-iustice majority together. Butler wrote in his docket book: "limit strictly to foreign." CSC, Justice Butler, United States v. Curtiss-Wright Export Corp., docket book (1936); and in recording the vote in his docket book, Brandeis made the following entries next to the names of three of the justices: Butler- "foreign"; Sutherland - "foreign affairs"; Van Devanter —-"foreign affairs." Brandeis made no similar notation next to the names of the other four members of the majority. CSC, Justice Brandeis, United States v. Curtiss-Wright Export Corp., docket book (1936). Sutherland may have avoided the second narrow ground of decision in part because Hughes's opinion in Panama Refining Co., 422-30, discounted the constitutional significance of those prior delegations.

20. The congressional authorization meant that no "independent" executive power was at issue in Curtiss-Wright, and Sutherland's dichotomy meant that the delegation was valid because it addressed "external" matters. For a thoughtful contrary view, see Lofgren, "'Government From Reflection, '” 204-5.

21. Van Der Weyde v. Ocean Transport Co., 297 U.S. 114, 117 (1936). In an easily distinguishable case decided in November, Valentine v. United States ex rel. Neidecker, 299 U.S. 5, 18 (1936), the Court unanimously denied a claim of independent executive power involving foreign relations, rejecting the contention that the president had power to extradite American citizens absent authorization by treaty or statute.

22. The Constitution itself provided virtually no support for the Court's assertion, and Sutherland's opinion barely mentioned its provisions. White, Constitution and the New Deal, 73-74. As Edward S. Corwin famously stated, the Constitution's overlapping grants of foreign affairs powers to Congress and the executive only created for the two branches "an invitation to struggle for the privilege of directing American foreign policy." Edward 
views on foreign affairs powers in order to assert the "plenary and exclusive" nature of the executive's power? Why did Brandeis join an opinion that contained such unnecessary constitutional language and affirmed the existence of the kind of independent-and, therefore, unchecked-executive power that he so consistently opposed? Why did seven of eight sitting justices agree to accept such potentially broad and significant language that was both novel and unnecessary?

\section{6: Politics and Foreign Policy}

Initially, Curtiss-Wright's emphasis on the president's "plenary and exclusive power" in foreign affairs might seem an understandable response to the ominous world situation that confronted the United States. World War I brought the Bolshevik revolution in Russia, the threat of an international communist-inspired revolutionary movement, and a vastly more active role for the United States in world politics, commerce, and finance. The following years unleashed a mounting series of new and unnerving challenges: the rise of Fascism in Italy and elsewhere, a catastrophic worldwide depression, Japanese aggression and conquest in Asia, the triumph of Nazism in Germany, the Italian invasion of Ethiopia, and German rearmament and avowed expansionism. Then, in 1936-as Curtiss-Wright made its way to the Court-came Japan's withdrawal from the London Naval Conference and its rapid expansion of the Imperial Navy, the German occupation and remilitarization of the Rhineland, the outbreak of the Spanish Civil War, German and Italian recognition of the Spanish Fascist government, and the announcement of the Rome-Berlin Axis alliance. Finally, one week after the oral argument,

S. Corwin, The President: Office and Powers, 1787-1957 4th rev. ed. (New York: New York University Press, 1957), 171. Moreover, in its section asserting the executive's "plenary and exclusive" power (Curtiss-Wright, 319-22), the opinion cited no compelling, or arguably even relevant, nonconstitutional sources. It quoted a statement by John Marshall in the House of Representatives in 1800 and a Senate report from 1816, both involving the president's power "to speak or listen as a representative of the nation" (Curtiss-Wright, 319). Then, it cited President George Washington's refusal to provide the House with documents relating to the negotiation of the Jay Treaty (Curtiss-Wright at 320-21), the deferential practice of Congress in seeking information about foreign affairs from executive departments (Curtiss-Wright, 321-322), and a case that declared that "the United States is invested with all the attributes of sovereignty" and that "the powers of nationality" were especially strong in dealing with foreign affairs. Curtiss-Wright, 322 (quoting Mackenzie v. Hare, 239 U.S. 299, 311 [1915]). All of those sources are limited and easily distinguishable, and none of them required-or arguably even supported-the Court's sweeping assertion about unspecified "plenary and exclusive" executive power. 
while the case was sub judice, Germany and Japan announced that they had signed an anti-Comintern pact directed at the Soviet Union. ${ }^{23}$ The resulting fears of another and far more destructive world war stretching across Europe and Asia could have made the need for strong executive leadership in foreign affairs seem undeniable.

Such an understanding, however, would be incomplete at best, if not essentially mistaken, because most Americans simply did not draw that conclusion. To the contrary, they seemed to reject it and to exhibit a growing distrust of executive power and discretion in foreign affairs. Therefore, the Court's language about "plenary and exclusive" executive power was not only novel and unnecessary, but it also promised to be highly unpopular and widely controverted. Clearly, Curtiss-Wright was not simply an unavoidable or consensus response to the foreign challenges that confronted the nation.

The 1930s witnessed a fiercely contested national debate over American foreign policy. At political center stage an unusually assertive, if internally divided, Congress deeply suspicious of executive discretion in foreign affairs squared off against a powerful president who sought to assert and, if possible, expand that discretion. ${ }^{24}$ Both sides were committed to keeping the country out of war, but they disagreed radically on the way to do so.

"Neutralists" and "isolationists" feared executive power and discretion. Acutely suspicious of international bankers and arms manufacturers, and convinced that foreign entanglements could drag America into a new war, they were animated above all by memories of President Woodrow. Wilson's role in leading the country into "the Great War" despite his much-heralded promises to the contrary. Some were also driven with special fervor by a rabid distrust of Roosevelt himself, warning angrily that he was-like Hitler and Mussolini-seeking dictatorial powers and even planning secretly to lead the nation into war. While a few insisted on clinging to the letter of international law and maintaining "neutral" commercial relations with all belligerents, the great majority-citing Wilson's fatal insistence on upholding America's rights as a neutral--

23. See, generally, George C. Herring, From Colony to Superpower: U.S. Foreign Relations Since 1776 (New York: Oxford University Press, 2008), ch. 12; and David M. Kennedy, Freedom from Fear: The American People in Depression and War, 1929-1945 (New York: Oxford University Press, 1999), chs. 13-14.

24. Robert Dallek, Franklin D. Roosevelt and American Foreign Policy, 1932-1945 (New York: Oxford University Press, 1979), esp. 47-48, 71-72 and chs. 4-6; and Robert A. Divine, The Illusion of Neutrality: Franklin D. Roosevelt and the Struggle Over the Arms Embargo (Chicago: University of Chicago Press, 1962), esp. chs. 3-5. 
advocated legislation limiting or prohibiting commerce with belligerents as the only way to keep the country out of war. ${ }^{25}$

In contrast, Roosevelt and his supporters--"internationalists" and "interventionists"--believed that executive discretion was essential. Inspired by a broader internationalism, a growing awareness of the threat posed by Nazism and Fascism, and a faith in Wilsonian principles of collective security, they believed that effective cooperation among nations offered the best hope of preserving world peace, thereby keeping America out of future wars. Consequently, they argued that the president needed flexibility to meet changing international threats and that any congressional limitation on American commerce should allow the president discretionary authority to use the nation's economic power in combination with other nations to deter potential "aggressors." If the feared war did come, many or most also believed mandatory embargo laws would work in favor of Nazi Germany and Fascist Italy. They would disadvantage smaller and unprepared nations victimized by attack, and prevent Britain from taking full advantage of its naval superiority and maintaining essential wartime trade with the United States. ${ }^{26}$

In the early and mid-1930s, the neutralists and isolationists held the upper hand, and the political balance tilted markedly against the president. In 1934, Congress, led by Republican Senator Hiram Johnson of California, an isolationist and "irreconcilable" opponent of the League of Nations, restricted the nation's financial involvement with Europe by prohibiting private loans to countries that defaulted on their World War I debt obligations, and the following January the Senate-refleeting widespread hostility to the League and sharpening anti-foreign sentiments-once again rejected American membership in the Permanent Court of International Justice, the so-called "World Court." The next year, Protestant clergy joined pacifist, women's, and veterans' groups in establishing the antiwar Emergency Peace Campaign, while hundreds of thousands of college students rallied against war on 130 campuses. "Beginning in early 1935,"

25. Divine, Illusion of Neutrality, ch. 4; and George Wolfskill, The Revolt of the Conservatives: A History of the American Liberty League (New York: Houghton Miffin, 1962). In a 1936 poll, $45 \%$ of Americans stated that Roosevelt's policies might lead to dictatorship. Benjamin L. Alpers, Dictators, Democracy, and American Public Culture: Envisioning the Totalitarian Enemy, 1920s-1950s (Chapel Hill: University of North Carolina Press, 2002), 80. For the contrasting approaches of the neutralists, see Edwin Borchard and William Lage, Neutrality for the United States (New Haven: Yale University Press, 1937) (urging strict adherence to international law and neutral rights); and James Brown Scott, "The Neutrality of the Good Neighbor," Proceedings of the American Society for International Law 29 (1935): 1-25 (urging abandonment of neutral rights and imposition of arms embargos).

26. Dallek, Franklin D. Roosevelt; and Divine, Illusion of Neutrality. 
David M. Kennedy explained, "American isolationism hardened from mere indifference to the outside world into studied, active repudiation of anything that smacked of international political or military engagement."27

Responding to the country's isolationist mood, Congress adopted more direct measures. In August of 1935, it passed a "neutrality act," prohibiting the export of "arms, ammunition, or implements of war" to all belligerent nations, although leaving some discretion for the president to define "implements of war" and determine when an embargo should go into effect. Six months later, in February 1936, it adopted a second "neutrality act" that tightened the restrictions imposed in the initial legislation and added new ones. The 1936 act prohibited American loans to belligerents, limited the president's discretion in invoking the embargo, denied him authority to limit trade in raw materials, and required him to extend the embargo to any nation that subsequently joined a conflict. By 1936, intensifying antiwar sentiment made popular distrust of national foreign policy so pervasive that $71 \%$ of respondents in a Gallup Poll favored a constitutional amendment that would limit the power of Congress by requiring a popular national referendum to approve a declaration of war. ${ }^{28}$

Therefore, although grave foreign policy concerns loomed when the Court heard Curtiss-Wright, those concerns by themselves were insufficient to explain the majority's decision to assert the executive's "plenary and exclusive" power in foreign affairs. That striking declaration of executive power was neither an unavoidable response to foreign threats and the fear of a coming war, nor the consensus product of either congressional or popular opinion. Nor was it legally compelled or necessary to the decision. Curtiss-Wright's executive power language stemmed from other sources, and those sources were within the Court itself.

\section{Hughes}

Charles Evans Hughes projected a commanding presence. With great charm, a powerful intellect, rigorous self-discipline, and a vast capacity for work, he carved out a stellar career as a public investigator, govemor of New York, associate justice of the Supreme Court, Republican presidential candidate, United States secretary of state, author of multiple books on law and international affairs, senior partner in a leading New York law firm, judge on the Permanent Court of International Justice, and president

27. Herring, From Colony to Superpower, 504; and Kennedy, Freedom from Fear, 393.

28. Dallek, Franklin D. Roosevelt, 108, 120; Divine, Illusion of Neutrality, 85, 115-16, 158; and George H. Gallup, The Gallup Poll: Public Opinion, 1935-1971 (New York: Random House, 1972), 1:35. 
of New York's Legal Aid Society, the American Bar Association, and the American Society for International law. In 1930, he added appointment as Chief Justice of the United States. He was a man of vast experience, immense personal prestige, and nearly unparalleled professional and political accomplishment. His appearance, moreover, accentuated his achievements. Tall, erect, white-bearded, and stern-looking, he seemed to more than one observer a "Jovian figure." 29

By temperament and experience, Hughes was an executive, a person who exercised power repeatedly and in a variety of high offices. He believed firmly in his own judgment, and he strove vigorously to expedite whatever business fell to his care. Especially in foreign affairs, he readily understood the need for executive independence and discretion. A principal inducement that led him to accept the office of secretary of state was President Warren Harding's promise that he would enjoy an essentially free hand to run the department and guide the nation's foreign relations. ${ }^{30}$

As secretary of state from 1921 to 1925 , Hughes tried to do just that. He reorganized the State Department, asserted firm control over its activities, and persuaded Congress to make major reforms in the Foreign Service. More dramatic, during his first year in office, he organized the famous Washington Disarmament Conference. There, he prevailed upon the world's major powers to accept substantial limitations on their naval forces and to settle a number of contentious issues involving China and the Far East, an effort that produced three major treaties involving nine of the world's most powerful nations. With that achievement, James Simon wrote, "Hughes emerged as one of the world's leading statesmen."31

Constitutionally, Hughes operated on a thoroughly executive-centered theory of foreign affairs law. He insisted on the president's exclusive

29. William G. Ross, The Chief Justiceship of Charles Evans Hughes, 1930-1941 (Columbia, SC: University of South Carolina Press, 2007); and Paul Freund, "Charles Evans Hughes as Chief Justice," Harvard Law Review 81 (1967): 4-43. On Hughes as a "Jovian" figure, see Roger K. Newman, Hugo Black: A Biography (New York: Pantheon Books, 1994), 269; and Freund, "Charles Evans Hughes," 13.

30. Charles A. Beard, The Idea of National Interest: An Analytical Study in American Foreign Policy (New York: Macmillan Company, 1934), 420; Betty Glad, Charles Evans Hughes and the Illusions of Innocence: A Study in American Diplomacy (Urbana, IL: University of Illinois Press, 1966), 132-33, 138-39; and Merlo J. Pusey, Charles Evans Hughes (New York: Macmillan Company, 1951), 2:412, 431.

31. Pusey, Charles Evans Hughes, 2:411-12, 419-20, chs. 41-49 passim; and James Simon, FDR and Chief Justice Hughes: The President, the Supreme Court, and the Epic Battle Over the New Deal (New York: Simon \& Schuster, 2012), 3. On Hughes as secretary of state, see Dexter Perkins, Charles Evans Hughes and American Democratic Statesmanship (Boston: Little, Brown \& Company, 1956); and Glad, Charles Evans Hughes, chs. 17-18. 
control over the conduct of foreign policy and on his right to assert privilege against senatorial efforts to obtain confidential communications involving treaty negotiations. Responding to an inquiry from Republican Senator Henry Cabot Lodge, the chair of the Senate Foreign Relations Committee, Hughes insisted on "the right of the Executive, acting through the Secretary of State, to determine the instructions to be given to agents in the exercise of the authority of the Executive in the conduct of foreign affairs." He was firm and forceful. "The conduct of foreign relations pertains to the executive power," he insisted. "Practice under the Constitution has abundantly confirmed the initiative of the President in the formulation of foreign policy." Hughes made it clear, moreover, that he was personally committed to upholding the principle of exclusive executive foreign affairs power. "I should not favor a change in the distribution of power or any modification of practice," he announced, "which would encourage the notion that the Executive is responsible to the legislative branch of the Government in matters which under the Constitution are exclusively of executive concern." 32

Hughes maintained that Congress properly played only a limited role in foreign affairs. Its powers were limited to specific constitutional grants, and - even more restrictive - those powers imposed a positive duty. Congress, he argued, was obligated to provide funding for the exercise of the executive's constitutional prerogatives. ${ }^{33}$

Hughes's experience as secretary of state not only confirmed his belief in strong and independent executive leadership in foreign affairs, but it also soured him on the Senate's role in the area. Although he sought to cultivate friendly relations with Congress and enjoyed a number of successes, his tenure was marked by repeated and frustrating battles with a proud Senate leadership determined to assert control over the nation's foreign policy. During the presidential campaign of 1920 Hughes had announced his support for ratifying the Treaty of Versailles with reservations, and as secretary of state he approached ratification as his first major goal. The "irreconcilables" and "strong reservationists" in the Senate blocked his

32. Glad, Charles Evans Hughes, 143, 147; Pusey, Charles Evans Hughes, 2:499-500; Hughes Papers, Library of Congress (hereafter CEHP), reel 33: Hughes to Lodge, Feb. 6, 1923, 2; and Charles Evans Hughes, "Some Observations on the Conduct of Our Foreign Relations," American Journal of International Law 16 (1922): 367, 368. "Premature disclosures may prevent the accomplishment of the most enlightened aims," and "it is fatuous to suppose that negotiations can be conducted without prudent reservations on each side." Ibid., 369.

33. Glad, Charles Evans Hughes, 143. See Charles Evans Hughes, "Some Aspects of the Work of the Department of State," American Journal of International Law 16 (1922): 355-64. 
efforts, however, and Hughes was forced to abandon ratification as a lost cause. The same Senate bloc also frustrated his initial plan to bring a formal end to the war with Germany by adopting a revised version of the Treaty of Versailles. The Senate finally agreed to a separate German peace treaty only after Hughes drafted an entirely new document that accepted the controlling language of a congressional resolution and merely cross-referenced provisions of the Treaty that conferred rights on the United States. Worse, the Senate insisted on an additional provision designed to block Hughes's efforts to facilitate American cooperation with the League of Nations. It required that the United States "not be represented or participate in any body, agency, or commission" of the League without congressional approval. Subsequently, the Senate defeated his heartfelt effort to have the United States adopt the convention that established the World Court. ${ }^{34}$

While Congress proved an insurmountable obstacle to some of his principal ambitions, Hughes achieved other critical goals by simply ignoring or eluding its constraints. He avoided the restriction on American participation in League activities by appointing "unofficial" representatives to attend conferences, keep the State Department informed, and spread the views of the United States to League members. More boldly, when the Senate opposed his proposal to establish a commission to settle war claims between Germany and the United States, he invoked the constitutional power of the executive to conclude international agreements without Senate approval and, through a series of diplomatic notes, established the commission solely on the authority of the executive. Similarly, when he sought to resolve the pressing problem of German war reparations by pushing what became the "Dawes Plan," he established an "independent" committee of financial experts to study the problem and then traveled to Europe to persuade the Allied governments in person to adopt its recommendations. He was subsequently candid about his personal diplomacy. "If I had sought to obtain the consent of Congress to the appointment of a committee officially representing our Government," he explained, "I should have been involved in a controversy which would have defeated the entire plan." 35

34. Glad, Charles Evans Hughes, 140-41; 143, 151-52, 185-92, 215-16; Pusey, Charles Evans Hughes, 1:395-99, 404; 2:431-34, 571, 611-12; Charles Evans Hughes (David J. Danelski, and Joseph S. Tulchin, eds.), The Autobiographical Notes of Charles Evans Hughes (Cambridge, MA: Harvard University Press, 1973), 226; and Charles Evans .Hughes, "The Permanent Court of International Justice," Proceedings of the American Society for International Law 17 (1923): 75-89.

35. Glad, Charles Evans Hughes, 178, 218; Pusey, Charles Evans Hughes, 2:443-44; and Hughes, Autobiographical Notes, 260. See Glad, Charles Evans Hughes, 223-30. 
Repeatedly, Hughes bridled at what he regarded as congressional willfulness, irresponsibility, and obstructionism. In 1922, he used a commencement address at the University of Michigan to lay out his views. The nation's "instrumentalities of foreign intercourse" have "suffered from too much regard for politicians," he announced, "and too little attention to the necessity for special aptitude and training." Those who conducted the nation's foreign affairs were qualified professionals who often possessed "special information available only to officers of the Government." Urging the public to acquire a broader understanding of foreign countries and, more pointedly, Congress itself to listen more respectfully to the advice of executive officials, Hughes struck at his antagonists. "The chief enemies of peace are those who constantly indulge in the abuse of foreign peoples and their governments, who asperse their motives and visit them with ridicule and insult." Such enemies might adopt a "pseudo-patriotic spirit," but their actions were taken "most probably in the interest of local politics." Such politically inspired actions threatened to defeat "peaceful settlements which are eminently judicious, and which really promote the safety of the country." Hughes concluded bluntly. "The principal difficulty at this time in our conduct of foreign affairs is not with method, or organization, or aims," he declared, "but with the untruthful, prejudiced and inflammatory discussions in which some of our citizens and certain portions of the press permit themselves to indulge." 36

In private, his comments were far more biting, and they were aimed directly at the Senate. "I am at a loss to understand how those who have attained the high position of senator can permit themselves to indulge in reckless characterization of other peoples" in "their opposition to the work of the [Washington Disarmament] Conference." Such actions were "so injurious to the conduct of our foreign relations." It was "certainly cause for anxiety when the results of the most earnest endeavor under American auspices come so near to defeat at the hands of the Senate." The United States could not enjoy the "prestige and influence" it deserved, he protested bitterly, "if we are thus betrayed in our own homes." 37

Similarly, Hughes viewed congressional attacks on Japanese immigration as another "very sorry business" that "implanted the seeds of an antagonism which are sure to bear fruit in the future." Bemoaning the resulting "substitution of antagonism for cooperation in the Far East," he again blamed the Senate. "Our friends in the Senate have in a few minutes spoiled the work

36. Hughes, "Some Observations," 366, 370-72. "We have," he emphasized, "had recent illustration of this." Ibid., 370-71.

37. CEHP, reel 28: Hughes to Frank H. Hiscock, March 24, 1922. See Pusey, Charles Evans Hughes, 2:441, 463, 499-500, 512-17, 574-75. 
of years and done a lasting injury to our common country." Public criticisms of the Senate's excesses were "entirely justified," he declared, and the Senate's constant meddling made him "greatly depressed." 38

For Hughes, then, the language in Curtiss-Wright about the "plenary and exclusive" foreign affairs power of the executive was hardly unfamiliar, unjustified, or unwanted. Indeed, it would have seemed to him precisely on target. His inbred executive temperament, his experience and tactics as secretary, his anger and resentment at the Senate, and his carefully articulated views on the independent and exclusive constitutional powers of the executive all confirmed the rightness of that language. The Senate, moreover, surely revived Hughes's distressing memories of his frustrations with its earlier ill-informed and "injurious" foreign policy actions when in early 1935 it once again rejected American membership in the World Court, membership that Hughes had long urged and a court on which he himself had proudly served from 1928 to 1930 . The principles Hughes advocated in the 1920s paralleled the executive power language of Curtiss-Wright, and those principles were far different from anything that Sutherland had advanced in his pre-Court writings. Consequently, it seems most probable that it was Hughes-not Sutherland-who "won" the Court in Curtiss-Wright and inspired its "plenary and exclusive" executive foreign affairs power language. ${ }^{39}$

That Hughes would use his position as chief justice and his persuasive powers as an advocate to advance his strongly held views on executive foreign affairs power seems undeniable. ${ }^{40}$ "While the Chief Justice has

38. CEHP, reel 28: Hughes to Hiscock, March 24, 1922; Hughes to Hiscock, April 6, 1922; and Hughes to Hiscock, April 24, 1924. See Hughes, Autobiographical Notes, 212-22, 242, 249.

39. Herring, From Colony to Superpower, 504; and Hughes, Autobiographical Notes, 222-25. Pusey wrote his biography with Hughes's close cooperation. Pusey, Charles Evans Hughes, 1:vii. The finished product was exceptionally favorable to Hughes, and generally reflected his point of view. Pusey's language describing Curtiss-Wright, then, may be suggestive. Pusey stated that Sutherland "wrote a scholarly opinion confirming the broad sweep of the President's power in international affairs." Ibid., 2:745 (emphasis added). It seems plausible to speculate that the word "confirming"-itself a highly debatable characterization-came from Hughes himself and that Pusey's use of that word reflected Hughes's belief that Sutherland's opinion embodied Hughes's own long-held view about the nature of executive foreign affairs power. See note 44 below.

40. Pusey states that Hughes did not "solicit support for his views outside the conference," Pusey, Charles Evans Hughes, 676, and Hughes seemed to confirm some such practice. "Very rarely, and then only casually, did I discuss cases with any Justice in advance of the conferences of all the Justices." Hughes, Autobiographical Notes, 301. Roberts once stated that Hughes never asked him to change his vote in a case. Richard D. Friedman, "Charles Evans Hughes as Chief Justice, 1930-1941: The Complexities of Moderation,"(unpublished M Phil diss., Oxford University, 1979) (on file with author), 373. Those statements do not 
only one vote, the way in which the Court does its work gives him a special opportunity for leadership," he explained in 1928. "At the conference it is the practice for the Chief Justice, unless he desires otherwise, to be the first to state his opinion with respect to the case to be decided." As chief justice,

contradict the argument in the text and, moreover, require some qualification. As an experienced and determined leader, Hughes "actively sought" to secure large, and, if possible, unanimous decisions. Danelski and Tulchin, "Editors' Introduction," in Hughes, Autobiographical Notes, xxvi. First, and likely most important, Hughes regularly expressed his views fully and forcefully in the Saturday conferences. Second, he communicated through memos responding to draft opinions, and he was ever ready to suggest modifications if he thought them necessary. For example, see George Sutherland Papers, Library of Congress, box 4 (hereafter GSP), Sutherland to Hughes, December 28, 1936. Third, Hughes's self-denying statement in his Autobiographical Notes contains loopholes. It seems to acknowledge occasional advance discussions, and it fails to exclude either discussions of "issues" (as opposed to "cases") or conversations about cases held after conferences. Finally, substantial evidence shows that Hughes did sometimes communicate privately with other justices about pending issues and cases: Andrew L. Kaufman, Cardozo (Cambridge: Harvard University Press, 1998), 479 (Hughes visited Cardozo's apartment on several occasions to dissuade him from publishing proposed separate opinions) and $694 \mathrm{n} .31$ (Roberts admitted that Hughes pressed him to add certain constitutional language to his opinion in United States v. Butler, 297 U.S. 1 [1936]). The added language in Butler gave an independent scope to the General Welfare Clause, and Hughes later declared that language to be "the most significant and important" part of the case. Hughes, Autobiographical Notes, 309. For his part, Roberts acknowledged that he had given in to Hughes's urging and remarked that he "often wonder[ed] why the hell I did it just to please the Chief." Richard D. Friedman, "Switching Time and Other Thought Experiments: The Hughes Court and the Constitutional Transformation," University of Pennsylvania Law Review 142 (1994): 1946; Newman, Hugo Black, 282 (Hughes persuaded Black to write for the Court in a delicate race case by promising to "get the Court" for him); Pusey, Charles Evans Hughes, 2:757 (Hughes and Roberts have "private chat" about the latter's vote in West Coast Hotel v. Parrish, 300 U.S. 379 [1937]); Philippa Strum, Louis D. Brandeis: Justice for the People (Cambridge: Harvard University Press, 1984), 369-70 (Brandeis informed Hughes that he "couldn't stand for" a McReynolds opinion, and Hughes arranged for Van Devanter to negotiate changes with McReynolds and, when objections remained, took over the opinion himself and made changes to satisfy Brandeis); Harlan F. Stone Papers, Library of Congress, box 75 (hereafter HFSP), Hughes to Stone, November 24, 1934 and Stone to Hughes, November 24, 1934 (Hughes agrees to conference at his home with Brandeis, Stone, and Cardozo); and Joseph L. Rauh, JA., Melvin H. Siegel, Ambrose Doskow, and Alan Strook, "A Personal View of Justice Benjamin N. Cardozo: Recollections of Four Cardozo Law Clerks," Cardozo Law Review 1 (1979): 17 (Doskow: Hughes came "into the apartment to persuade Cardozo not to publish [a proposed concurrence] separately").

The claim that in the summer of 1936 Hughes tried to persuade Roberts to alter his views on pending cases (see William E. Leuchtenburg, "Charles Evans Hughes: The Center Holds," North Carolina Law Review 83 [2005]: 1999) would add further support, but questions have been raised whether the evidence underlying the claim actually supports it. Barry Cushman, "The Hughes-Roberts Visit," Green Bag, Second Series 15 (2012): 125-47. 
Hughes "set out for Saturday conference with some very pronounced views on how each [case] should be disposed of," and he "actively sought" unanimity or near-unanimity in the Court's decisions. Invariably, he spoke first and made his opinion clear. Those conferences "lasted six hours," Brandeis later recalled, "and the Chief Justice did all the speaking." 11

When Curtiss-Wright came before the Court, moreover, Hughes would have harbored no doubt that the president's action was constitutional and that the congressional resolution should be upheld. In his defense of executive power in the 1920s, he had, in effect, already decided the issue. The foreign affairs power of the executive, Hughes announced in 1928, included the power to impose arms embargos on nations in the Western Hemisphere. If the president "finds that in any American country conditions of domestic violence exist, which are promoted by the addition of arms or munitions of war procured in the United States," the president is empowered "to put an embargo upon the exportation of such arms or munitions of war from the United States to any such country." Although Hughes did not specify the source of the president's power, he seemed to suggest that it was of constitutional stature, because he cited no statutory authority and declared that any resulting embargo would carry "such limitations as the President may prescribe." 42 The hypothetical embargo he described in 1928 fit the embargo in Curtiss-Wright precisely.

Equally important, Hughes's practical understanding of the use of embargos would most likely have made him particularly sympathetic to Roosevelt's position in the debates over neutrality legislation. The proper application of embargos, Hughes had maintained, depended upon shrewd pragmatic judgments, the kinds of judgments that Roosevelt and his supporters insisted were necessary to make embargos effective as a method of preserving the peace. The decision to impose an arms embargo, Hughes explained in 1928, presented questions that were "delicate"-the same word that Curtiss-Wright later used to describe the foreign affairs powers of the executive - and that required sophisticated practical judgments involving "choices which all, even governments, must make between good and evil in a world of moral decisions." To make such

41. Charles Evans Hughes, The Supreme Court of the United States (New York: Columbia University Press, 1928), 58; Edwin McElwain, "The Business of the Supreme Court as Conducted by Chief Justice Hughes," Harvard Law Review 63 (1949): 14; Danelski and Tulchin, "Editors' Introduction," in Hughes, Autobiographical Notes, xxvi; Alpheus Thomas Mason, Harlan Fiske Stone: Pillar of the Law (New York: The Viking Press, 1956), 789.

42. Charles Evans Hughes, Our Relations to the Nations of the Western Hemisphere (Princeton: Princeton University Press, 1928), 51. See Glad, Charles Evans Hughes, 244, 250-51. 
difficult choices wisely, "each case must be judged on its own merits." If highly individualized and pragmatic decision making in "each case" was essential to employ embargos effectively, legislation mandating rigid and across-the-board prohibitions --the kind of laws that the president's neutralist and isolationist adversaries sought to impose-would be profoundly unwise as a matter of national policy and highly dubious as a matter of public morality. When Hughes considered Curtiss-Wright, then, he would not only have regarded the president's proclamation as constitutional, he would also most likely have sympathized with Roosevelt's appeal for discretionary powers and regarded the mandatory proposals of his isolationist and neutralist adversaries as unwise and dangerous. ${ }^{43}$ Hughes in that case would have felt no reluctance-especially in addressing an arms embargo imposed upon two South American countries-in urging the justices to uphold the government and affirm the principle of executive power and independence in foreign affairs. ${ }^{44}$

For Hughes, moreover, the time was ripe, and Curtiss-Wright was a serviceable vehicle for such a pronouncement. ${ }^{45}$ Although he maintained a

43. Hughes, Our Relations, 53, 54. Butler's docket book seems to indicate that, when Hughes stated the case in conference, he "expressed view findings not mere op[inion]." CSC, Justice Butler, United States v. Curtiss-Wright Export Corp., docket book (1936) (emphasis in original). This would support the claim that Hughes took the lead in urging the justices to uphold the delegation. See note 44 below. In foreign policy, Hughes was a pragmatic realist who believed that nations would invariably follow their "essential interests." Hughes, Autobiographical Notes, 221; and Pusey, Charles Evans Hughes, 2:439. Hughes and Roosevelt had long enjoyed a cordial and mutually respectful relationship (Simon, FDR and Chief Justice Hughes, 6, 8, 230, 314, 384); and Sutherland's opinion also seemed to echo the importance of practical considerations. Curtiss-Wright, 320.

44. Intriguingly, the first of three brief notations in Brandeis's docket book may provide additional evidence of Hughes's leadership in the conference. The entry begins with the letters "CJ" and continues with words that seem to be "as to additional" and then words that could be "ground of." The remaining words have not been identified. CSC, Justice Brandeis, United States v. Curtiss-Wright Export Corp., docket book (1936).

45. Hughes was acutely aware that the Court's decisions could influence the conduct of foreign policy. As secretary of state, for example, the Court's Prohibition enforcement decisions had caused him considerable difficulty. Pusey, Charles Evans Hughes, 2:576-77. Beyond the foreign threats that challenged the nation, Hughes may also have had an additional reason for wishing to incorporate the "plenary and exclusive" language, a reason that he would not likely have shared with the Court as a whole. He may have seen Curtiss-Wright as an opportunity to help defuse the intense political controversy over the New Deal that surrounded the Court in late 1936. Curtiss-Wright was only one of several relatively "liberal" decisions that the Court handed down in the weeks between the presidential election in November and the announcement of Roosevelt's Court-packing plan on February 5, 1937. Ross, Chief Justiceship, 97101. The executive power language would surely please Roosevelt and his supporters, and it might also signal that the Court was not adamantly opposed to either national power or the New Deal. As chief justice, Hughes was anxious to protect the Court in a time of looming 
nearly complete public silence on controversial issues, he was nonetheless deeply disturbed by events in Europe, fearful of a new world war, and likely sympathetic with the plight of German Jews. ${ }^{46}$ Only months after Curtiss-Wright was decided Hughes could not resist making vague but pointed comments on the world situation. Asked to deliver an address at a college alumni luncheon, he warned his audience that "the institutions of democracy are threatened by an authoritarian philosophy" and by "a regime of force" that imperiled the world. "Ruthlessness in trampling upon the rights of individuals in the exercise of the brute strength of the majority, if unchecked," he declared, "will inevitably lead to the entire overthrow of democratic processes and the substitution of the tyranny of force." 47

If Hughes had urged the "plenary and exclusive" executive power language on the justices, his exhortation would have carried great weight. The chief justice's "actual influence will depend upon the strength of his character and the demonstration of his ability in the intimate relations of the judges," he had written in 1928, and in those qualities Hughes excelled. He was a superb administrator who worked assiduously to streamline

constitutional crisis, and such a deft signaling effort seemed well within his tactical imagination. Only months later, Hughes used his tactical skills to protect the Court when he worked adroitly behind the scenes to send a crucial but quite different political signal: that Congress should reject the president's Court-packing plan. Not without reason did Roosevelt later declare Hughes "the best politician in the country." Jeff Shesol, Supreme Power: Franklin Roosevelt vs. the Supreme Court (New York: W.W. Norton \& Company, 2010), 400.

46. As early as 1922, Hughes received diplomatic warnings about Hitler's "vehemence and fanaticism" in seeking a "dictatorship," and that his growing poputarity meant that the German people were "slowly going mad." Pusey, Charles Evans Hughes, 2:580-81. Subsequently, Hughes blamed World War II on Hitler's rearmament of Germany and the failure of England and France in the mid-1930s to stop him when they could. Hughes, Autobiographical Notes, 220. At three Soviet Embassy dinners during the 1930s, Hughes spoke with the Russian ambassador. On the last occasion, in May 1938, the two men "surveyed at length the rising menace of Hitlerism in Europe," and the ambassador insisted "rather emphatically that Hitler, as soon as he was ready, would attack France." Pusey, Charles Evans Hughes, 2:529. Hughes's likely sympathy with the plight of German Jews may be inferred from the fact that he had previously shown his opposition to anti-Semitism, and urged better relations between Christians and Jews. In 1927, he had helped found the National Conference of Christians and Jews. Pusey, Charles Evans Hughes, 2:621-22. Less than 2 months before Curtiss-Wright was argued, the Conference publicly hailed Hughes as one of its founders. CEHP, reel 81: Everett R. Clinchy to Hughes, September 21, 1936, with enclosed press release. See note 100 below.

47. Pusey, Charles Evans Hughes, 2:762, 764. Hughes presumably intended his remarks as a condemnation of Nazism and Fascism as well as a warning about the dangers of Roosevelt's Court-packing plan. Six months before Pearl Harbor, he declared that the "lamps of justice are dimmed or have wholly gone out in many parts of the earth." Charles Evans Hughes, "Address of the Honorable Charles Evans Hughes," Proceedings of the American Law Institute, 18 (1941): 29. 
internal procedures and ensure that the Court stayed abreast of its caseload. In preparing for Saturday conferences, he told his biographer, he invested "an immense amount of work" to master the record in all the cases. In conference, he presented issues clearly and concisely, and he kept discussions sharply focused. In the delicate task of assigning opinions, he sought to spread both the general workload and major cases fairly among all the justices. Finally, in personal relations, he was invariably courteous to his colleagues, sought to accommodate their concerns when possible, and remained on cordial terms with all. Persistently he worked to create and preserve as much harmony as possible on a deeply divided Court, and he retained the high regard of all the majority justices. ${ }^{48}$

Further, in Curtiss-Wright, Hughes's views would probably have carried greater weight than usual. The justices knew that he was not only broadly experienced in foreign relations but that he also possessed extensive experience in Latin American affairs. As secretary of state, he had dealt with most of the countries in the hemisphere and, among other achievements, had at one point helped to avoid a threatened war between Peru and Chile. After leaving the State Department, he wrote a book on American foreign policy in Latin America, and in 1928, he headed the American delegation to the Sixth Pan-American Conference in Havana. Having previously helped resolve several South American boundary disputes, as chief justice he served in 1932 and 1933 as president of a three-person arbitration commission that settled a long-standing boundary conflict between Guatemala and Honduras. He continued, in addition, to deal with issues that had arisen while he was secretary of state, and on several occasions, he drew on his State Department expertise to help his colleagues with the Court's business. ${ }^{49}$

48. Hughes, Supreme Court, 57, 61; Pusey, Charles Evans Hughes, 2:664-65, 669-70, 672-79, 790-91; Ross, Chief Justiceship, ch. 8; Edward L. Carter, and Edward E. Adams, "Justice Owen J. Roberts on 1937," Green Bag, Second Series 15 (2012): 386; Hughes, Autobiographical Notes, 301; Felix Frankfurter, "Chief Justices I Have Known," Virginia Law Review 39 (1953): 901; and Freund, "Charles Evans Hughes," 40. Cardozo told Roberts that, given Hughes's persuasive powers, he waited 24 hours before making his decision in cases in which Hughes had made a particularly forceful argument in favor of one position. For his part, Roberts believed that Hughes's arguments in conference and his mastery of the facts of cases "often persuaded his brethren on the Court to change their minds and side with him." Carter and Adams, "Justice Owen J. Roberts," 386. As for assignments, Cardozo was a slight exception. Although admiring Hughes, Cardozo felt that he did not receive his share of important cases. Kaufman, Cardozo, 479.

49. Pusey, Charles Evans Hughes, 2:546-48; Hughes, Our Relations; Hughes, Autobiographical Notes, 274; CEHP, reel 118: Memorandum, "The Guatemala-Honduras Boundary" (undated); Glad, Charles Evans Hughes, 257-58; HFSP, box 75, Hughes to Stone, November 12, 1931; HFSP, box 60, Hughes to Stone, December 1, 1933; CEHP, 
Finally, while the Court was considering Curtiss-Wright, world events further highlighted the salience of Hughes's South American expertise and the critical importance of both executive leadership and hemispheric harmony. To the accompaniment of widespread fanfare and tumultuous receptions, Roosevelt visited Rio de Janeiro and Montevideo in early December on an extended trip to attend a Pan-American conference in Buenos Aires. There, the president sought to unify the hemisphere behind common policies, including the use of embargos that would apply if and when local wars erupted, exactly the kind of situation that the congressional resolution in Curtiss-Wright addressed. Although Roosevelt's effort failed, his tour reflected growing anxieties about a coming war, exemplified the president's pivotal role in foreign affairs, and underscored the need to maintain peace and unity in the Western Hemisphere. ${ }^{50}$

Roosevelt's efforts in Buenos Aires, the continuing battle over congressional neutrality legislation, and the multiplying foreign threats that loomed could only have confirmed in Hughes's mind the wisdom of executive independence in foreign affairs and the need for executive discretion in the use of embargos. Given his firm commitment to those principles and his determination to lead the Court, it seems highly probable that he urged the language of "plenary and exclusive" power on the justices. Given the respect he commanded on foreign affairs law and the obvious challenges the nation faced from abroad, it seems equally probable that some, and quite likely all, of those who joined the majority found his arguments convincing. ${ }^{51}$

reel 5: William Phillips (under-secretary of state) to Hughes, March 8, 1934, legal advisor, Department of State, memoranda on "Abrogation of Treaties," January 27, 1936, and "Memorandum for the Chief Justice," January 29, 1936; Carlos Salazar (Counsel for Guatemala) to Hughes, January 25, 1933; Hughes to David Koppman, January 30, 1932; Mark Sullivan to Hughes, July 29, 1935; and Hughes to Richard Hooker, Jan. 14, 1936. At the Havana conference, Hughes defended the right of the United States to intervene in Latin American affairs. Dallek, Franklin D. Roosevelt, 82.

50. Franklin D. Roosevelt, "The President Suggests to All the American Republics an Inter-American Conference at Buenos Aires to Advance the Cause of American and World Peace," January 30, 1936, in Public Papers and Addresses of Franklin D. Roosevelt (New York: Random House, 1938), 5:72; and Dallek, Franklin D. Roosevelt, 132-34.

51. The docket books of Brandeis, Butler, and Roberts all indicate that the vote in conference was identical to the final lineup of the justices when the opinion was announced. Therefore, the conference was apparently decisive. For Hughies's influence on the individual justices, see note 135 below and accompanying text and citations. 


\section{Sutherland}

If Hughes was the driving force behind Curtiss-Wright, the question remains why Sutherland agreed to alter his long-established views and accept the chief justice's executive-centered position. He would surely not have done so because he trusted or hoped to benefit Roosevelt, a person he regarded as "quite unfit and unsafe for the presidency." It "remains a mystery," H. Jefferson Powell recently noted, "why Sutherland himself reworked in the president's favor the theory that Curtiss-Wright gave him the chance to write into law." 52

The solution to the mystery seems to lie in the compelling impact of events. By 1936, Sutherland's personal situation as well as his institutional position had changed drastically, and both the politics of American foreign policy and the dangers that threatened from abroad were radically different. Sutherland was ready to adapt.

A career Republican politician, Sutherland was a Party spokesman and activist when he wrote his earlier works. He had served in the Utah State Senate and then in the United States House of Representatives, and in 1905 he began two successive terms in the United States Senate. Defeated for re-election in 1916, he stayed in Washington, practicing law and remaining closely involved in Republican Party affairs. When a seat opened on the Court in 1922, he was an obvious choice, for reasons that went far beyond his undoubted ability and well-earned reputation for legal acumen. He was thoroughly sound from the party's point of view, and he was ideally connected. The president was his friend and ex-Senate colleague Warren Harding, whom he had enthusiastically supported in the election of 1920; the Senate was controlled by his other ex-colleagues in the Party by a whopping margin of 22 votes; and the highly influential Chief Justice William Howard Taft, a conservative Republican who worked assiduously with the new administration to place "loyal teammates" on the federal bench, "heartily endorsed" his appointment. ${ }^{53}$

In the years before he went on the Court, Sutherland's personal position and his party's politics virtually ensured that he would stress the "co-ordinate" role of Congress and reject any idea that the executive

52. Van Devanter Papers, Library of Congress (hereafter WVDP), box 17, letterbook 45A, 189, Van Devanter to Dennis T. Flynn, October 3, 1932; Powell, "Story of Curtiss-Wright," 225.

53. Paschal, Mr. Justice Sutherland, 105-8; GSP, box 2, Sutherland to Warren G. Harding, November 10, 1920 ("Your overwhelming victory is the most joyous thing that ever happened"); Alpheus Thomas Mason, William Howard Taft: Chief Justice (New York: Simon and Schuster, 1965), 171. 
possessed "plenary and exclusive" foreign affairs powers. When he wrote his 1910 article, he was a Senator, and by the time he published Constitutional Power and World Affairs in 1919, he had spent 12 years in the upper chamber, the last 6 as a member of the Senate Foreign Relations Committee where, frequently and forcefully, he announced his opinions and his party's positions on the foreign affairs issues of the day. ${ }^{54}$

Sutherland's pre-Court writings, moreover, were not merely wellconsidered jurisprudential essays but also carefully shaped political tracts. In his 1910, article, for example, he repeatedly stressed the difference between the national government's unlimited "external" powers and its strictly limited "internal" powers. Tellingly, he defended a restrictive version of the commerce power that would bar a variety of labor related reform proposals and emphasized, in particular, that the limited nature of the federal government's "internal" powers prohibited it from enacting a national child labor law, at the time a paramount goal of Progressives across the nation. In discussing "external" powers, Sutherland failed even to consider the ways in which they were allocated between Congress and the executive, the Republicans having controlled both the White House and the Senate since 1898. Focusing only on the "national" nature of foreign affairs power, he treated "external" powers as undifferentiated by branch and belonging simply to the "General Government" or the "National Government." 55

More importantly, by 1919, when he published Constitutional Power and World Affairs, the Democrats held the presidency for the 7th straight year, and Sutherland had established himself as a persistent and sharptongued critic of the administration. Repeatedly he decried President Wilson's excessive and dangerous power, charging that the president simply "issues orders" to supine Democrats in Congress and thereby controlled the whole government. His attacks were often "bitter," his sympathetic biographer acknowledged, because Sutherland regarded Wilson's

54. Sutherland, Constitutional Power, 76, 123; David T. Canon, Garrison Nelson, and Charles Steward III, Committee in the U.S. Congress (1789-1946): Senate Standing Committees (Washington, DC: CQ Press, 2002), 2:530-31; and Paschal, Mr. Justice Sutherland, 93-96.

55. Sutherland, "Internal and External Powers," Sen. Doc. 417, 2, 10-12. Sutherland did not oppose all Progressive reforms and supported, in particular, women's suffrage and relatively narrow workmen's compensation laws that did not "encourage the indolent" and that maintained "the vital distinction between helplessness, which is a misfortune, and laziness, which is a vice." George Sutherland, "The Economic Value and Social Justice of a Compulsory and Exclusive Workmen's Compensation Law," Sen. Doc. 131 (1913), quoted in Samuel R. Olken, "Justice George Sutherland and Economic Liberty: Constitutional Conservatism and the Problem of Factions," William \& Mary Bill of Rights Journal, 6 (1997): 40 . 
ideas as "unsound" and his embrace of Progressivism as the act of "a turncoat." 56

In those pre-Court years, Sutherland would have especially scorned the language of "plenary and exclusive" executive power because it was the hated Wilson who hailed executive leadership and proclaimed the "very absolute" power of the president in foreign affairs. "The initiative in foreign affairs, which the President possesses without any restriction whatever," Wilson declared boldly and sweepingly, "is virtually the power to control them absolutely." Not only did Wilson trumpet the executive's "absolute" foreign affairs powers, but he also made the exercise of those powers an intensely personal matter. The president "must stand always at the front of our affairs," he announced, "and the office will be as big and as influential as the man who occupies it." 57 Wilson's claim that the executive power was largely a matter of personal character, combined with his early successes and his arrogant and self-righteous manner, drove Republicans to outraged fury.

Most decisive, when Sutherland published his book in 1919, he was passionately engaged in the fierce Republican campaign against Wilson's handling of the Paris Peace Conference and his support for the Treaty of Versailles and the League of Nations. "I am in very grave doubt," Sutherland declared in September 1918, "as to the wisdom of the entire movement for a league." 58 As long as Wilson was president and the monumental battle over ratification raged, Sutherland would hardly have dared advance the idea that the executive possessed independent and exclusive foreign affairs powers. Nothing was more essential to the Republican's anti-Wilson campaign than the contrary principle that Congress shared the nation's "external" powers and played an equal role in shaping its foreign policy.

Moving beyond the position he advanced in 1910 that "external" powers were simply "national" powers, Sutherland's 1919 book introduced an extensive consideration of the Constitution's allocation of powers among the branches, and it proclaimed that the foreign affairs powers of

56. Paschal, Mr. Justice Sutherland, 82-87, 93-95 (quotes at 83, 93, and 82). Sutherland termed one of Wilson's actions "utterly subversive of every consideration of self-respect." Ibid., 93. Sutherland was likely particularly distressed by Wilson's emphasis on the Constitution as a "living" document that allowed governmental changes, especially the growth of federal power in domestic areas. Woodrow Wilson, Constitutional Government in the United States (New York: Columbia University Press, 1908), 54-57, 69, 192-93.

57. Wilson, Constitutional Government, 77, 79.

58. GSP, Box 2, Sutherland to Frederick E. Wadhams, Septmber 16, 1918. Sutherland gave his lectures in December, 1918, and the book was published in early 1919. For Sutherland's criticisms of the League, see Sutherland, Constitutional Power, ch. 8, esp. 184-91; and Sutherland to Warren G. Harding, November 10, 1920. Sutherland blamed Wilson for the fate of the Treaty and the League. GSP, Box 2, Sutherland to W.W. Keen, December 29, 1919. 
Congress and the executive were "co-ordinate." Its pages echoed the sounds of the ratification battle. Implicitly challenging Wilson, who had refused to name a single Senator to the American delegation to the peace conference, it insisted that the Senate had the right to participate "in the making of treaties at any stage of the process." Directly reprimanding Wilson, it declared bluntly that "no wise President" would fail to consult the Senate in negotiating a treaty. Broadly warning him, it declared that once "a treaty has been transmitted to the Senate for its action, the power of that body is plenary." Indeed, it announced, Congress should never follow the executive with "blind obedience" and "must exercise its own judgment" on matters of foreign policy. "Any other course," Sutherland charged, "involves a double betrayal of official trust-usurpation of power by the President and abdication of duty on the part of Congress." 59

Thus, Sutherland's 1919 book advanced the Republican's political and constitutional case against Wilson, his foreign policy, and his general theory of executive leadership. It declared that the "potency and influence" of the executive had expanded "to an extent never dreamed of" by the Founders and that "executive domination" threatened the Constitution's system of separated national powers. Those who saw the president as the "sole repository" of the people's sovereignty-a pointed reference to Wilson and his supporters - were "[v]ery decidedly" wrong. ${ }^{60}$

In warning against excessive executive power, Sutherland's book tracked the central theme of his party's attacks on Wilson's entire presidency, a theme that carried through to the election of 1920, which Wilson hoped to make a referendum on the Treaty and the League. Then, the Republican platform pledged to "end executive autocracy and restore to the people their constitutional government," while the party's presidential candidate promised to honor the constitutional role of Congress by returning to "party government, as distinguished from personal government, individual, dictatorial, autocratic."61 For Sutherland and the Republican Party in 1919-20, the idea of "plenary and exclusive"

59. Sutherland, Constitutional Power, 76, 123, 126, 127.

60. Sutherland, Constitutional Power, 75. For similar jabs at Wilson, see ibid., 110 (denying executive control of the war power despite "prevalent opinion to the contrary"), 22 (rejecting the idea of making the world "safe for democracy"), 166 (same), and 172 (scorning the idea of "a war to end war"). For Sutherland's views before he joined the Court, see GSP, box 2, Sutherland to W. W. Keen, December 29, 1919; George Sutherland, "Principle or Expedient?" Proceedings of the Forty-Fourth Annual Meeting of the New York State Bar Association (1921), 263, 273; and Paschal, Mr. Justice Sutherland, 82-85.

61. James L. Sundquist, The Decline and Resurgence of Congress (Washington, DC: The Brookings Institution, 1981), 12; and Lindsay Rogers, "American Govemment and Politics," American Political Science Review 16 (1922): 41. 
executive power in foreign affairs - the power allegedly sought by the despised and "autocratic" Wilson-was anathema.

Sixteen years later, however, when Sutherland wrote his opinion in Curtiss-Wright, everything had changed. First, Sutherland was free from the demands of party politics, the pressures of the ratification debate, and the infuriating goad of Wilson and his arrogance. He was free, too, from the political constraints that his own ambition for a seat on the Court had imposed on him, an ambition that had been dependent upon loyalty both to his party and to the foreign policy prerogatives of the Senate. Therefore, in 1936 Sutherland could view foreign affairs issues from a broader, more pragmatic, and far less politically and personally involved perspective. Further, his service on the Court, especially his close association with Chief Justice Taft and Taft's profound commitment to upholding executive power, may also have fostered a new understanding of the desirability of executive independence and discretion. ${ }^{62}$

Second, Sutherland had become convinced that Nazi Germany was a menace to the world and that a new world war was rapidly approaching. Born in England, he retained a strong sense of his English background and a strong affection for his country of origin. In Constitutional Power and World Affairs he praised his native land as the "home of religious and political tolerance" and the "birth-place of Anglo-Saxon liberty." Germany he condemned as a "wild beast," a "contemptible and cowardly" nation that for 40 years had "coldly plotted" war and "forgot there was a human soul." By 1936, Sutherland saw Germany planning a repeat performance. He believed that the "fear of Germany" he found in England and France was entirely justified, and he was "very disturbed over the war situation in Europe." The future, he reported, "looks very ominous." Indeed, he declared, "unless there is a radical change in circumstances, a great war in the course of a few years seems almost inevitable." 63

62. Sutherland had been rumored for a place on the Court since his first term in the Senate, and he undoubtedly had a keen desire for the appointment. Paschal, Mr. Justice Sutherland, 60, 111-14. Under the leadership of Henry Cabot Lodge, Senate Republicans were determined to assert a strong, and perhaps decisive, voice in shaping American foreign policy. See, for example, Henry Cabot Lodge, "Foreign Relations of the United States, 19211924," Foreign Affairs 2 (1924): 525-39. For Taft, see Mason, William Howard Taft, 205; Myers v. United States, 272 U.S. 52 (1926) (Taft, C.J.); and J. W. Hampton, Jr. \& Co. v. United States, 276 U.S. 394 (1928) (Taft, C.J.). Sutherland joined Taft's opinion for the Court in both cases. The author thanks Robert Post for the suggestion about Taft's possible influence. Hadley Arkes suggests that Sutherland's ideas about executive power might have changed because he became convinced that only the executive could effectively direct the nation's foreign affairs. Arkes, Return of George Sutherland, 235-41.

63. Paschal, Mr. Justice Sutherland, 218 and n.28; Sutherland, Constitutional Power, 3, 7 , 4; and GSP, box 4, Sutherland to S. Hughes, March 16, 1936. In January 1937, Sutherland 
Third, the threat of Nazism and the likelihood of war would have activated the hard lessons he had drawn from the First World War. One was that only military might could preserve the peace. "Surely," Sutherland declared, "we have by this time discovered that it is weakness, and not strength, which invites attack." A second was that the security of the United States consequently required an extensive and long-term program of military preparedness. He urged an expansion and modernization of the standing army, "a thorough-going system of universal compulsory military training" for all males older than 14 years of age, and the creation of a powerful two ocean navy to counter "the contingency of a combination of European and Asiatic powers against us." Third, and most immediately relevant in 1936, was the fundamental lesson that he himself stressed with an exclamation point. "Yield nothing to the aggressor!" Sutherland was uncompromising in accepting the fact that wars were sometimes unavoidable. "A state of war is always dreadful," he declared, "but it is a sweet and holy thing compared with a peace of ignoble capitulation to wrong." 64

For Sutherland, then, the ties of his English birth and cultural affinity likely combined with his growing anxieties over German expansionism and a coming world war, his commitment to American military preparedness, and his deep conviction that the nation should "yield nothing" to aggressors to lead him to favor an anti-Nazi foreign policy and accept the wisdom of Hughes's views on arms embargos and the foreign affairs powers of the executive. On most other issues of foreign affairs law, the two had long held similar views. They agreed, for example, that the war powers of the national government were complete and fully adequate to meet any possible foreign challenge and that those powers were supreme and exclusive with respect to the states. Writing for the Court only 2 years before Curtiss-Wright, Hughes had sounded very much like the pre-Court Sutherland when he insisted on the "sovereign prerogative" of the United States on all "international questions" and declared that in such cases "a State has no prerogative." 65 Agreement on such fundamental principles

continued to see conditions in Europe as "disturbing," but sounded more hopeful. He thought that England was "doing the best thing possible" to "avert a general war and was "inclined to think that such a terrible calamity will be avoided." GSP, box 4, Sutherland to H. Wesbury Preston, January 9, 1937.

64. Sutherland, Constitutional Power, 172-183 (quotes at 174, 175, 179, 181, 182). Sutherland may also have been impressed with Roosevelt's efforts at the Pan-American Conference in Buenos Aires, because he believed that the "Monroe Doctrine is an essential part of our defensive policy" and "a matter of grave national importance." Sutherland, Constitutional Power, 22.

65. Compare Charles Evans Hughes, "War Powers Under the Constitution," Marquette Law Review 2 (1918): 9 with Sutherland, Constitutional Power, 96; and Monaco 
would have made it relatively easy for Sutherland to reconfigure his earlier theory and incorporate Hughes's position that in foreign affairs the executive held "plenary and exclusive" power.

Hughes, of course, selected Sutherland to write for the Court. Had he found Sutherland resistant to his views, he could have assigned the case to another justice or, more appropriately, written it himself. Hughes was invariably purposeful in assigning cases ${ }^{66}$ and in selecting Sutherland he must have been confident that he would secure an opinion that he could readily join and, most probably, one that would reflect his own convictions-in 1936 more critical than ever-about the independent foreign affairs power of the executive.

The key to understanding Sutherland's change of position, then, would seem to lie in the contrasting pressures and conditions he confronted, not simply the emergence of new foreign dangers in the 1930s but more tellingly in the passing of the old political battles of his pre-Court years. In addressing questions of foreign affairs law, Sutherland was flexible and pragmatic, far more so than he was in dealing with issues of domestic law. ${ }^{67} \mathrm{He}$ had carefully molded his earlier writings to serve his contemporaneous political purposes. In 1910, he discussed not only the nature of the national government's "external" powers, but also emphatically underscored the sharply limited nature of its "internal" powers. Thus, he was able to argue that the national government lacked power to enact a national child labor law and other similar Progressive proposals. In

v. Mississippi, 292 U.S. 313, 331 (1934). Hughes made statements similar to those in Monaco in Burnet v. Brooks, 288 U.S. 378, 396 (1933); Valentine v. United States ex rel. Neidecker, 299 U.S. 5, 8 (1936); and Board of Trustees of the University of Illinois v. United States, 289 U.S. 48,59 (1933), and he also supported a broad scope for the treaty power. Santovicenzo v. Egan, 284 U.S. 30, 40 (1931). Sutherland joined Hughes's opinions in all of those cases. See Hughes, Supreme Court, 102-11; and Pusey, Charles Evans Hughes, Vol 1, 369-70. Sutherland also agreed with Hughes that in foreign affairs, nations were guided by their own perceived self-interest and that the establishment of a world court was a highly desirable goal and a promising method of maintaining world peace. See note 43 above and Sutherland, Constitutional Power, 176-77, 188-91.

66. "[I]n making assignments," Hughes later explained, "I often had in mind the special fitness of a Justice for writing in the particular case." Hughes, Autobiographical Notes, 302. See Hughes, Supreme Court, 59. Sutherland also seemed a perfect choice because of his familiarity with the subject, his ability to write quickly, and the likelihood that the three conservatives would be more likely to accept a centralizing opinion from him. Powell, "Story of Curtiss-Wright," 220-21.

67. Sutherland's "internal/external" dichotomy was designed to seal off the domestic realm from the realm of foreign affairs. It preserved the principle that the power of the national government in "internal" matters was limited to "delegated and enumerated" powers while, at the same time, opening the nation's foreign policy to more flexible, uncabined, and expedient national actions. 
1919, when war and the urgent challenges of postwar foreign policy led him to focus more carefully on "external" powers, he moved beyond his earlier conception of unallocated "national" powers to develop a theory of allocated branch powers that were shared and "co-ordinate." Thus, he was able to argue that the Senate's power over treaties was "plenary," that it should scorn "blind obedience" to the executive, and that it had a constitutional "duty" to exercise an independent judgment on issues of foreign policy. That 1919 position seemed firmly anchored in his and his party's intense antipathy to Wilson and in their concerted opposition to the Treaty of Versailles and the League of Nations. As those galvanizing issues faded during the following decade and a half, however, so too did Sutherland's commitment to the constitutional formulations of 1919. By the mid-1930s, when both threatening world conditions and his own institutional position and foreign policy concerns had changed drastically, he was ready once again to remold his position to serve new and quite different purposes.

\section{Brandeis}

If Sutherland's change of position seemed puzzling, Brandeis's decision to join the majority appeared equally so. Curtiss-Wright violated Brandeis's philosophy of judicial restraint and conflicted with some of his most basic constitutional principles. In the past, in fact, Brandeis had criticized Sutherland for going beyond the facts of cases when he wished to "settle things." Sutherland, he believed, "had to be held in check." 68 Curtiss-Wright seemed a perfect opportunity for him to try to do so.

By 1936, Brandeis had developed a series of elaborate doctrines of constitutional avoidance. Less than a year before Curtiss-Wright was decided, he had issued his famous Ashwander concurrence, in which he drew on dozens of precedents to identify seven specific rules whereby the Court "has avoided passing upon a large part of all the constitutional questions pressed upon it for decision." Curtiss-Wright manifestly violated two of those rules: It decided a question of constitutional law unnecessarily, and it formulated a constitutional rule broader than "the precise facts" required." 69

68. Melvin I. Urofsky, "The Brandeis-Frankfurter Conversations," Supreme Court Review (1985): 31 .

69. Ashwander v. Tennessee Valley Authority, 297 U.S. 288, 341, 346-47 (1936) (Brandeis, J., concurring). Brandeis urged constitutional avoidance, for example, in Hill v. Wallace, 259 U.S. 44, 72 (1922) (Brandeis, J., concurring); Lipke v. Lederer, 259 U.S. 557, 563 (1922) (Brandeis, J., dissenting); Pennsylvania v. West Virginia, 262 U.S. 553, 
More compelling, Sutherland's opinion conflicted with four of Brandeis's fundamental constitutional principles: that governmental centralization should be avoided when possible, that federal judicial power should be carefully limited, that Congress held constitutional primacy in American government, and that executive power should always be subject to checks. ${ }^{70}$ Contrary to those principles, Curtiss-Wright encouraged centralization of power in the national executive, seemed to make the judiciary the primary constitutional check on executive foreign affairs powers, ${ }^{71} \mathrm{lim}$ ited and, to some uncertain extent, denied congressional power in foreign affairs, and asserted independent power in the executive that was beyond the authority of Congress to check. Only one year earlier, Brandeis had given voice to his deep suspicion of executive power when he joined the Court in limiting the president's power to remove members of independent regulatory agencies. "If men on the Federal Trade Commission and similar government agencies are not allowed to exercise their independent judgment," he explained about the decision, "we should have in effect a dictatorship or a totalitarian state." 72

No fundamental sympathy with Sutherland's political or jurisprudential views, moreover, would have induced Brandeis to join his Curtiss-Wright opinion in the face of those principles. Before their Court days, the two had tangled repeatedly as adversaries at opposite ends of the political spectrum, and on the Court they divided over on a range of pivotal issues. When

605 (1923) (Brandeis, J., dissenting); and King Manufacturing Co. v. City Council of Augusta, 277 U.S. 100, 115 (1928) (Brandeis, J., dissenting). See Alexander M. Bickel, The Unpublished Opinions of Mr. Justice Brandeis (Chicago: University of Chicago Press, 1957), xvi.

70. Edward A. Purcell, Jr., Brandeis and the Progressive Constitution: Erie, the Judicial Power, and the Politics of the Federal Courts in Twentieth-Century America (New Haven: Yale University Press, 2000), 120-32, 165-77, 190-91; Arthur M. Schlesinger, Jr., The Politics of Upheaval (Boston: Houghton Mifflin Company, 1960), 280; Melvin I. Urofsky, Louis D. Brandeis: A Life (New York: Pantheon Books, 2009), 705-6 and ch. 11; Myers v. United States, 272 U.S. 52, 240, 292-93 (1926) (Brandeis, J., dissenting); and Humphrey's Executor v. United States, 295 U.S. 602 (1935).

71. Sutherland's view of the role of the judiciary in foreign-affairs law was unclear. His earlier article ("Internal and External Powers," 7 [Sen. Doc. 417]), his book (Constitutional Power, 46, 144, 156), and his opinion (Curtiss-Wright, 320) all acknowledged the existence of constitutional or extraconstitutional limitations on executive and national foreign affairs powers, limitations that could be taken to imply judicial enforceability. However, he also argued that some foreign affairs questions involving "political policies" were not "justiciable or susceptible of decision by the application of the principles of law or equity." Sutherland, Constitutional Power, 134. See G. Edward White, "The Transformation of the Constitutional Regime of Foreign Relations," Virginia Law Review 85 (1999): 60-62.

72. Humphrey's Executor; Alpheus Thomas Mason, Brandeis: A Free Man's Life (New York: The Viking Press, 1946), 619. 
Curtiss-Wright was decided in 1936, the fever-pitch battle over the constitutionality of the New Deal had entered its most heated phase, and Brandeis and Sutherland stood in the Court's rival wings, caucusing with different colleagues and splitting sharply in the term's most decisive constitutional decisions. ${ }^{73}$

Nor would Brandeis have joined the majority for reasons of tactics or deference. Although he recognized the virtues of judicial consensus and sometimes accepted opinions that he thought dubious, he would hardly have followed that course in Curtiss-Wright. Judicial unanimity and wellsettled rules were desirable in "ordinary cases" where "it doesn't matter terribly how you decide so long as [a rule] is settled," he explained. But there was a "special function of dissent in constitutional cases" in which the issues involved "statesmanship." On those issues, Brandeis insisted, "nothing is ever settled" until done so wisely and rightly, when "statesmanship is settled and at an end." 74 Therefore, given the sweeping nature of Sutherland's constitutional language and the vast import of the principles at stake, neither tactical concerns nor institutional deference would likely have induced his agreement.

Brandeis's decision in Curtiss-Wright, then, seemed easily predictable. He would vote to uphold the government's prosecution on the straightforward ground that the president's proclamation was authorized by Congress.

73. Mason, Brandeis, 259-61; 276, 279, 499-500, 504; Samuel J. Konefsky, The Legacy of Holmes and Brandeis: A Study in the Influence of Ideas (New York: Collier Books, 1961), 278 n.54; Urofsky, Louis D. Brandeis, 574-75, 577. Although Brandeis and Sutherland agreed on some decisions both limiting and approving the exercise of governmental powers, they disagreed on many critical constitutional issues and divided on pivotal cases decided in the Court's 1936 term: West Coast Hotel Co. v. Parrish, 300 U.S. 379 (1937); National Labor Relations Board v. Jones \& Laughlin Steel Corp., 301 U.S. 1 (1937); and Steward Machine Co. v. Davis, 301 U.S. 548 (1937). Indicative of the division on the Court, Sutherland and the Court's other three conservatives were caucusing to prepare for the Court's Saturday conferences, and in 1936 the liberals began doing the same, Brandeis meeting with Cardozo and Stone to make counter-preparations. Kaufman, Cardozo, 477-78. The "conservative" wing, drawn together by Chief Justice Taft, had been meeting informally since the mid-1920s. Mason, Brandeis, 606. In spite of their political and legal disagreements, Brandeis and Sutherland enjoyed cordial personal relations. Paschal, Mr. Justice Sutherland, 116-17.

74. Bickel, Unpublished Opinions, 55-56; Strum, Brandeis, 346, 350-52, 364-71; Urofsky, Louis D. Brandeis, 579-81, 696-98; Robert C. Post, "The Supreme Court Opinion as Institutional Practice: Dissent, Legal Scholarship, and Decisionmaking in the Taft Court," Minnesota Law Review 85 (2001): 1341; and Urofsky, "Brandeis-Frankfurter Conversations," 309, 310, 314, 317, 327-9. See Burnet v. Coronado Oil \& Gas Co., 285 U.S. 393, 406 (1932) (Brandeis, J., dissenting) (stating, in addressing a nonconstitutional issue, that "in most matters it is more important that the applicable rule of law be settled than that it be settled right"). 
Filing a separate concurrence, as he had done earlier in the year in Ashwander, seemed his obvious course.

But Brandeis did not follow that course, as he did not invariably follow his principles of constitutional avoidance. His jurisprudence of restraint was not a rigid command, but a supple tool that he deployed to serve broader constitutional goals. When countervailing considerations weighed heavily, he was prepared to shade or ignore his Ashwander canon. ${ }^{75}$ The question, then, is what countervailing considerations moved him to do so in Curtiss-Wright?

Seemingly the most likely possibility was that Brandeis accepted Sutherland's opinion because he was willing to qualify his views on separation of powers when he addressed issues of foreign affairs law. Brandeis certainly gave vigorous support to national power in areas related to foreign affairs, such as commerce, treaties, Prohibition, and war. In addressing the comprehensive controls that the federal government imposed during World War I, for example, he consistently upheld the most farreaching assertions of national authority. Similarly, he was willing to give the Eighteenth Amendment an exceptional breadth, especially in dealing with its interstate and international enforcement. ${ }^{76}$

75. Evan Tsen Lee, Judicial Restraint in America: How the Ageless Wisdom of the Federal Courts Was Invented (New York: Oxford University Press, 2011), ch.4; Purcell, Brandeis and the Progressive Constitution, 120-32; and Shesol, Supreme Power, 453. See, for example, Gilbert v. Minnesota, 254 U.S. 325, 334, 343 (1920) (Brandeis, J., dissenting); United States ex rel. Milwaukee Social Democratic Publishing Co. v. Burleson, 255 U.S. 407, 417, 432 (1921) (Brandeis, J., dissenting); Olmstead v. United States, 277 U.S. 438, 471, 479 (1928) (Brandeis, J., dissenting); Whitney v. California, 274 U.S. 357, 372, 370-80 (1928) (Brandeis, J., concurring); and Erie Railroad Co. v. Tompkins, 304 U.S. 64 (1938) (Brandeis, J.).

76. On commerce, see, New York Central Railroad v. Winfield, 244 U.S. 147, 154 (1917) (Brandeis, J., dissenting); Arkansas Railroad Commission v. Chicago, Rock Island \& Pacific Railroad Co., 274 U.S. 597 (1927) (Brandeis, J.); Brandeis to Frankfurter, June 17, 1923, in Melvin I. Urofsky, and David W. Levy, eds., Letters of Louis Brandeis (Albany, NY: State University of New York Press, 1971-78), 5:78 [hereafter, Letters]. On the treaty power, see Missouri v. Holland, 252 U.S. 416 (1920). On Prohibition, see James Everard's Breweries v. Day, 265 U.S. 545 (1924); and Lambert v. Yellowly, 272 U.S. 581 (1926). On war powers, see Selective Draft Law Cases, 245 U.S. 366 (1918); Cox v. Wood, 247 U.S. 3 (1918); Hamilton v. Kentucky Distilleries Co., 251 U.S. 146 (1919) (Brandeis, J.); Northern Pacific Railway Co. v. North Dakota, 250 U.S. 135 (1919) (Brandeis, J., concurring alone in result without opinion); Ruppert v. Caffey, 251 U.S. 280 (1920) (Brandeis, J.); and Block v. Hirsch, 256 U.S. 135 (1921). On the Eighteenth Amendment, see Maul v. United States, 274 U.S. 501, 512 (1927) (Brandeis, J., concurring); United States v. Lee, 274 U.S. 559 (1927) (Brandeis, J.); and Robert Post, "Federalism, Positive Law, and the Emergence of the American Administrative State: Prohibition in the Taft Court Era," William \& Mary Law Review 48 (2006): 45, 137 n.45I. 
Brandeis's ready acceptance of national power in areas related to foreign affairs law, however, was not sufficient to align him with Sutherland's executive power language. In every case in which Brandeis upheld national power, the Court's decision rested on the authority of congressional legislation, not on any exclusive executive power, and it was to the legislature that Brandeis continually urged deference. In Curtiss-Wright, the presence of the congressional resolution readily explained why he would agree with the Court's result, but it explained equally why he would have found the opinion's language about "plenary and exclusive" executive power unnecessary and dangerous.

It is equally important that Brandeis's experience with both the war power and Prohibition enforcement had raised acutely troubling concerns. Both had led to a variety of egregious abuses-political repression, intrusions on privacy, and widespread violations of civil liberties - that convinced him of the need to impose limits on federal power. ${ }^{77}$ In a series of opinions after 1919, he articulated an increasingly muscular view of constitutional civil liberties, especially the right to freedom of speech. That right was invaluable, he insisted, because it protected freedom of thought, "the privacy and freedom of the home," and the "right of free men" to employ reason and public discussion "to strive for better conditions through new legislation and new institutions." By the late 1920 s, Brandeis's view of the war power and Prohibition enforcement had changed markedly, and by the mid 1930s, he had helped move the Court to provide more expansive judicial protections for constitutional civit tiberties. $^{78}$

77. Brandeis believed, for example, that the Department of Justice under Attorney General. A. Mitchell Palmer from 1919 to 1921 was "bent on suppression of knowledge." Brandeis to Frankfurter, March 17, 1924, in Melvin I. Urofsky and David W. Levy eds. "Half Brother, Half Son": The Letters of Louis D. Brandeis to Felix Frankfurter (Norman, OK: University of Oklahoma Press, 1991), 162. [hereafter, "Half Brother"]. On governmental repression during and after the war, see William H. Thomas, Jr., Unsafe for Democracy: World War $I$ and the U.S. Justice Department's Covert Campaign to Suppress Dissent (Madison, WI: University of Wisconsin Press, 2008); Robert K. Murray, Red Scare: A Study in National Hysteria, 1919-1920 (New York: McGraw-Hill Book Company, 1964); and William Preston, Jr., Aliens and Dissenters: Federal Suppression of Radicals, 1903-1933 (New York: Harper \& Row, 1963).

78. Gilbert v. Minnesota, 254 U.S. 325, 334, 335 (1920) (Brandeis, J., dissenting); Pierce v. United States, 252 U.S. 239, 253, 273 (1920) (Brandeis, J., dissenting). For Brandeis's other early opinions, see Schaefer v. United States, 251 U.S. 466, 482 (1920) (Brandeis, J., dissenting); and United States ex rel. Milwaukee Social Democratic Publishing Co. v. Burleson, 255 U.S. 407, 417 (1921) (Brandeis, J., dissenting). For his major opinions in the later 1920s urging greater judicial protection for civil liberties, see Whitney v. California, 274 U.S.357 (1927) (Brandeis, J.) (concurring on jurisdictional grounds and defending broad First Amendment rights); Gambino v. United States, 275 U.S. 310 
Moreover, Sutherland's "internal/external" dichotomy, which purportedly shielded domestic matters from the executive's extraconstitutional foreign affairs powers, would hardly have eased Brandeis's civil liberties concerns. His experience with the free speech cases that arose from the First World War and its aftermath had taught him one undeniable lesson: "internal" affairs could not always-perhaps ever-be insulated from "external" ones. Sutherland's doctrinal line was permeable at best and illusory at worst. Whatever powers "the nation" as a whole might possess over "external" affairs, they should not reside in unchecked form in the executive because, sooner or later, they would intrude repressively into domestic affairs.

Brandeis would also have been suspicious of Sutherland's views on foreign affairs law because Sutherland had insisted that the "power to declare war" meant that "freedom of speech may be curtailed or denied." Criticisms of the Sedition Act "on the ground that it unduly curtails freedom of speech and of the press," Sutherland had proclaimed in his 1919 book, "are wholly without justification." Writing for the Court in United States v. MacIntosh in 1931, Sutherland again emphasized that the comprehensive nature of the war power meant that "freedom of speech may, by act of Congress, be curtailed or denied so that the morale of the people and the spirit of the army may not be broken by seditious utterances." In his early free speech opinions, Brandeis had rejected Sutherland's position on the Sedition Act, and 12 years later, he readily recognized the dangers that lurked in the latter's MacIntosh opinion. Refusing to accept it, he joined Hughes's dissent. ${ }^{79}$

While those considerations warned Brandeis against Sutherland's opinion, however, two other factors apparently countered their influence and drew him toward it. One was the animating combination of his commitment to Zionism and his outrage at the threat of Nazism. The other

(1927) (Brandeis, J.) (broadening the Fourth Amendment exclusionary rule); Casey v. United States, 276 U.S. 413, 421, 423 (1927) (Brandeis, J.) (dissenting, criticizing government officers for entrapping defendants and courts for showing excessive "zeal to punish"); and Olmstead v. United States, 277 U.S. 438, 478-79 (1928) (Brandeis, J., dissenting) (denouncing federal wire-tapping as violating Fourth and Fifth Amendments). For his agreement with the Court's move in the early 1930 s to provide greater protections for civil liberties, see Near v. Minnesota, 283 U.S. 697, 722-23 (1931) (freedom of the press); Stromberg v. California, 283 U.S. 359 (1931) (freedom of speech); Powell v. Alabama, 287 U.S. 45 (1932) (right to counsel in criminal case); and Grosjean v. American Press Co., 297 U.S. 233 (1936) (freedom of the press). See also Hamilton v. Regents of the University of California, 293 U.S. 245, 265 (1934) (freedom of religion) (Brandeis and Stone, JJ., joining concurrence of Cardozo, J.).

79. Sutherland, Constitutional Power, 103; and United States v. MacIntosh, 283 U.S. 605, 622 (1931) (Sutherland, J.); 627 (Hughes, C.J. dissenting, joined by Brandeis, Holmes, and Stone, JJ.). 
was Hughes. In late 1936, the impact of the former likely made the views of the latter convincing.

Brandeis came to Zionism relatively late in life, but by World War I he had emerged as the leader of the American movement and, to some extent, of world Zionism. His overriding goals were to encourage Jewish settlement in Palestine and to foster the region's economic development. $\mathrm{He}$ not only provided direction and inspiration but also contributed generously from his own funds, donating more than $\$ 600,000$ to Jewish and Zionist causes. For him, Palestine represented not merely the dream of a Jewish homeland or even a haven for oppressed Jews, but something far broader: an opportunity to fulfill his deepest Progressive aspirations to build "a worthy self-supporting community." 80

Brandeis's early optimism about Palestine began to fade in the late 1920s. Repeated outbursts of Arab violence distressed him, and Britain's administration of its League of Nations mandate over the region appeared increasingly ineffectual. Stepping up efforts to secure American support for the Zionist cause, he met with little success. The United States government was committed to cooperating with Britain and maintaining cordial relations with the Arabs. ${ }^{81}$

When Adolph Hitler came to power in Germany in early 1933, Brandeis was so alarmed that only 6 weeks later he gave Jewish leaders the starkest advice. "The Jews must leave Germany." Nazism transformed Palestine from a dream, a refuge, and an opportunity into a desperately needed haven for safety and, perhaps, survival. German-Jewish immigration into Palestine began to accelerate, and both the British and the Arabs reacted with growing anxiety and hostility. American policy showed no change. ${ }^{82}$

80. The material on Brandeis and Zionism is drawn from several fine biographies. Mason, Brandeis, 441-64, 593-97, 635-37; Strum, Brandeis, 224-90, 384-85, 388-89; and Urofsky, Louis D. Brandeis, 399-429, 490-95, 515-44, 656-58, 685-90, 730-40. Specific statements in the paragraph appear in Strum, Brandeis, 225, 247, 287; Mason, Brandeis, 692; Melvin I. Urofsky, A Mind of One Piece: Brandeis and American Reform (New York: Charles Scribner's Sons, 1971), ch. 5; Brandeis to Julian Mack, December 1934; Brandeis to Wise, September 4, 1936; and Brandeis to Robert Szold, June 23, 1935 and October 5, 1936, Letters, 5:549, 576, 558-59, 582-83.

81. Brandeis to Frankfurter, August 27, 1929, September 6, 1929, and September 20, 1929 and Brandeis to Robert Szold, September 17, 1930, Letters, 5:382-86, 455; Leonard Baker, Brandeis and Frankfurter: A Dual Biography (New York: Harper \& Row, 1984), 338-39; Frank E. Manuel, The Realities of American-Palestine Relations (New York: Praeger, 1975 [1949]), 302-3; Evan M. Wilson, A Calculated Risk: The U.S. Decision to Recognize Israel (Covington, KY: Clerisy Press, 2008), 43-45, 47, 61-63; and Brandeis to Julian Mack, September 13, 1931 and January 3, 1932, Letters, 5:487, 491.

82. Letters, 5:554 n.4; Manuel, Realities of American-Palestine Relations, 300, 304. For the most recent, thorough, and balanced study of Roosevelt's policy toward Jewish 
Brandeis threw himself into the struggle against the terrifying new menace. He sought to persuade the Roosevelt administration to protest Nazi treatment of German Jews and to allow expanded Jewish immigration into the United States. In 1933, he met personally with Cordell Hull, Roosevelt's Secretary of State, to press his views. "America should adopt a policy of general admission [of Jews] and emphatic denunciation of German policy of discrimination," he argued, "so that the American [government] could invite other nations to follow our lead." He supported public protests, encouraged mass rallies, and backed a proposal to boycott German goods. By early 1934, he agreed with David Ben-Gurion, the leader of the Palestinian Jews whom he most admired, that Germany and Japan were preparing for war and that Palestine was the essential refuge of the Jewish people. "Palestine," Brandeis declared, "is the only hope." 83

Working through his many contacts, Brandeis sought assiduously to cultivate allies inside the administration, and Roosevelt himself offered a sympathetic ear. The President conferred personally with Brandeis about the worsening condition of German Jews and instructed the State Department to pass on to Zionists leaders any information received about developments in Palestine ${ }^{84}$ Beyond such token gestures, however, the president refused to act. In part, he was unwilling to alter the nation's long-established policies, and he regarded the Nazi treatment of German Jews as an internal matter in which he could not properly meddle. A variety of factors, moreover, limited his freedom of action, including an apparently rising domestic anti-Semitism, widespread fear of a possible war, and the general desire of most Americans to remain aloof from foreign involvements. Topping the list, of course, was the administration's all-consuming focus on combating the Depression. ${ }^{85}$

immigration, see Richard Breitman and Allan J. Lichtman, FDR and the Jews (Cambridge, MA: Harvard University Press, 2013).

83. Baker, Brandeis and Frankfurter, 341-43; Bruce Allen Murphy, The Brandeis/ Frankfurter Connection: The Secret Political Activities of Two Supreme Court Justices (New York: Oxford University Press, 1982), 70-71; and Brandeis to Wise, September 18, 1933, Brandeis to Julian Mack, October 17, 1933, Brandeis to David Ben-Gurion, January 25, 1934, Brandeis to Wise, April 11, 1935, Letters, 5:520, 524, 531, 533 n.2., 553. Brandeis supported a voluntary boycott but opposed proposals for an official United States boycott, Mason, Brandeis, 596, and he believed that Ben-Gurion deserved the "unqualified, ardent support" of all Zionists. Brandeis to Wise, June 2, 1936, Letters, 5:571.

84. Murphy, Brandeis/Frankfurter Connection, 419 n.124; Urofsky, Louis D. Brandeis, 734 40; and Brandeis Papers, University of Louisville (hereafter LDBP-L), reel 103: undated newspaper clipping from The Jewish Exponent (Philadelphia, August 14, 1936), Vol. 98, whole number 2570 (Roosevelt writes letter expressing support for "the rebuilding of the ancient Jewish homeland").

85. Manuel, Realities of American-Palestine Relations, 305; Strum, Brandeis, 384; and Frank Freidel, Franklin D. Roosevelt: A Rendezvous with Destiny (Boston: Back Bay 
Then, in April 1936, Palestine erupted in a wave of riots, strikes, and violence. Palestinian Jews sought to defend themselves and appealed to the British High Commissioner to restore order, but Arab leaders called for a general strike and escalated their agitation. Sporadic violence continued week after week, and the death toll mounted. Britain responded by increasing security measures, sending in military reinforcements, and announcing that it would establish a Royal Commission to investigate and recommend solutions. ${ }^{86}$

The crucial issue was Jewish immigration. In 1931, Prime Minister Ramsey MacDonald had declared that Britain would neither limit Jewish immigration nor restrict the sale of Arab lands to Jews, and between 1929 and 1936 the Jewish population jumped from 150,000 to 400,000 . The increase included some 164,000 Jewish immigrants, many from Nazi Germany, and raised the Jewish percentage of Palestine's population to $30 \%$. Arab leaders reacted by demanding the suspension of Jewish immigration and prohibiting the sale

Books, reprint ed., 1991), 112. In the 5 years after 1933, federal officials construed the immigration laws so strictly that nearly three quarters of the German quota went unfilled. In 1938, Roosevelt ordered changes that liberalized immigration policy and allowed 27,000 German and Austrian Jews to enter the United States during the following year. Dallek, Franklin D. Roosevelt, 166-67. Henry Feingold, The Politics of Rescue: The Roosevelt Administration and the Holocaust, 1938-1945 (New Brunswick, NJ: Rutgers University Press, 1970) emphasizes the range of severe limitations that constrained Roosevelt's freedom of action on the issue. Breitman and Lichtman, FDR and the Jews concludes that Roosevelt did little before 1936, but that he nonetheless "reacted more decisively to Nazi crimes against Jews than did any other world leader of his time" (p. 315), and that after 1936 he took actions that probably saved more than 100,000 Jews (p. 317). See, generally, Saul S. Friedman, No Haven for the Oppressed: United States Policy Toward Jewish Refugees, 1938-1945 (Detroit: Wayne State University Press, 1973); David S. Wyman, The Abandonment of the Jews: America and the Holocaust, 1941-1945 (New York: Pantheon Books, 1984); and Lucy S. Davidowicz, The War Against the Jews: 1933-1945 (New York: Bantam Books, 1986).

86. Reports varied considerably. For the report of the American Consul General in Jerusalem see Leland B. Morris to secretary of state, April 25, 1936, in Foreign Relations of the United States, 1936 (Washington, DC: United States Government Printing Office, 1953), 3:434-40 (hereafter, "Foreign Relations, 1936"). For other reports, see LDBP-L, reel 103: Sir Arthur Wauchope (British High Commissioner) to Ben Zvi, July 25, 1936; M. Shertok to Wauchope, July 25, 1936; Herschel v. Johnson, communication for the United States ambassador to the secretary of state (July 31, 1936), Foreign Relations, 1936 3:445; and "Report by His Majesty's Government in the United Kingdom of Great Britain and Northern Ireland to the Council of the League of Nations on the Administration of Palestine and Trans-Jordan for the Year 1936," http://unispal.un.org/ UNISPAL.NSF/0/FD4D250AF882632B052565D2005012C3, para. 67, 71 (hereafter "Report by His Majesty's Government"). See Michael B. Oren, Power, Faith, and Fantasy: America in the Middle East, 1776 to the Present (New York: W.W. Norton \& Company, 2007), 427. 
of land to Jews, measures that the Jews flatly rejected. The "gravest of all menaces" was "the possible suspension of immigration as a concession to Arab terror," the Zionist General Council concluded. Meeting in Zurich in late August, it declared "unanimously that such a suspension would have the gravest effects and that it must be averted at all costs." 87

Brandeis stayed closely informed through innumerable sources. Suspension of immigration would present "grave dangers" and threaten "the whole policy of the national Home," Ben Gurion wrote to him on July 5 , saying that the only "solution of our political difficulties within Palestine lies in increased immigration and an accelerated upbuilding of the National Home." Brandeis agreed wholeheartedly. The issue was so crucial, in fact, that he readily endorsed the practice of ignoring British limitations and illegally spiriting as many Jews as possible into Palestine. ${ }^{88}$

Through the summer months, the situation grew more perilous, and suspension rumors spread. Compounding the danger, several Arab countries launched diplomatic initiatives seeking to enter Palestinian affairs, interventions that the Zionists vigorously pressed Britain to reject. Worse, the Nazis also intruded, seeking to exploit the growing discord. They made new overtures to Arab leaders and invited the mufti of Jerusalem, one of the Arab leaders who had helped instigate the rioting, to visit Berlin. ${ }^{89}$

In late July, as the crisis deepened, Rabbi Stephen S. Wise-one of Brandeis's closest allies and the newly elected president of the Zionist Organization of America-rushed to London. The situation is "grave," he reported to Brandeis on July 21, and in cables to Zionist leaders in New York he issued a series of urgent directions, exhorting that "everything should be done in America opposing suspension." Fears deepened the next day, when the British secretary of state announced that the government was considering "a temporary suspension of immigration." The "news is not good," Wise informed Brandeis, "and it seems now as if nothing could avert suspension." 90

87. Oren, Power, Faith, and Fantasy, 426; John Quigley, Palestine and Israel: $A$ Challenge to Justice (Durham, NC: Duke University Press, 1990), 20; LDBP-L, reel 103: Ben-Gurion to Brandeis, July 5, 1936, 7, 9; William Ormsby Gore to Chaim Weizman, September 2, 1936; "Report of the Executive on the Meeting of the Zionist General Council," Zurich, August 25-31, 1936, 3; and "Report of the Meeting of the Administrative Committee of the Jewish Agency," September 2-3, 1936, 2.

88. Mason, Brandeis, 597; LDBP-L, reel 103: Ben-Gurion to Brandeis, July 5, 1936, 15-18; and Brandeis to Frankfurter, July 19, 1936, "Half Brother", 582-83.

89. Urofsky, Louis D. Brandeis, 739; LDBP-L, reel 103: "Note of Interview at the Colonial Office on September 30, 1936."

90. LDBP-L, reel 103: Wise to Brandeis, July 21, 1936 and Wise to "Zionists, New York," July 24, 1936; and "Report by His Majesty's Government," para. 71. On Wise and Roosevelt in 1936, see Breitman and Lichtman, FDR and the Jews, 91-92. 
As the situation continued to deteriorate, Wise secured a meeting with James Farley, chair of the Democratic National Committee, and Roosevelt's top campaign adviser. Farley, in turn, arranged another meeting with Hull, and telegraphed Roosevelt who was campaigning in Salt Lake City. Explaining that he was acting at the request of Brandeis as well as Wise and Felix Frankfurter, Farley told the president that "your help" in the Palestine immigration matter was "immensely important from every point of view." The next day, Wise met with Hull, and asked the secretary to speak with Roosevelt personally and secure his "permission to say to London" at the highest possible level that the president of the United States opposed the "threatened suspension" as a "disaster" for "the Jewish national Home." Hull promised to do so, and that night he reported to Wise that he had spoken with Roosevelt. The president was "tremendously concerned" and told Hull to direct the American ambassador in London to take action. Hull told Wise that he, in turn, had instructed the ambassador to make clear to the British government that the United States had a strong interest in avoiding suspension and that the president himself was personally concerned with the issue. ${ }^{91}$

Receiving Wise's report of the developments, Brandeis was overjoyed. It was, he congratulated his colleague, a "marvelous feat." Nothing more important had happened since the mandate itself, and it would now be "clear to Great Britain America's deep interest and particularly F.D. and Hull's views." Informing the British "what F.D. thinks," Brandeis continued, would have more effect "than the most emphatic legal opinion of all American lawyers" about Britain's obligations under the Mandate." Above all, it would show the British government "that F.D.'s administration 'means business'." 92

Brandeis's faith in Roosevelt was soon rewarded. On September 7, the British government condemned Arab violence, announced that it was sending "substantial reinforcements to Palestine," and implied that no major changes would be made in British policy until the Royal Commission completed its investigation. Then, on October 5, Wise met with Roosevelt personally, and the president informed him that Britain had "given up the idea of suspension because of your, (the American) interest." Wise praised the president for the "magnificently effective way" that the government had intervened and told him that "we can never be grateful enough." Then,

91. LDBP-L, reel 103: Wise to Brandeis, September 1, 1936.

92. Brandeis to Wise, September 4, 1936, Letters, 5:576. On September 2, Wise informed Brandeis that Ben-Gurion had cabled from Palestine urging that "we ask the President of the United States to use his influence with the British Government against the stoppage of immigration and the difficulties arising from such stoppage." LDBP-L, reel 103: Wise to Brandeis, September 2, 1936. 
as Brandeis had suggested, Wise pressed Roosevelt for further action. Telling the president that Brandeis supported his request, Wise asked that the government "supplement what it has done and put itself on record by sending an Aide-Memoire." Roosevelt agreed. "Stephen," he replied, "you tell Cordell [Hull] that I want him to do this and to send over whatever you and Felix [Frankfurter] prepare." 93

A month later Roosevelt's intervention bore its formal fruit. On November 5, the British secretary of state for colonial affairs announced that the government had "decided that a temporary suspension of immigration would not be justifiable on economic or on other grounds." Although it would impose additional quota limits, there would be no "drastic departure" from existing immigration policy "in advance of the findings of the Royal Commission." "94

Brandeis was delighted and immediately focused on gaining a favorable report from the Royal Commission. Insisting that "we must devote our efforts at present to the Palestine emergency," he declared that "America's deep interest" in Jewish affairs in Palestine "must be borne in upon the Commission." Repeatedly, he emphasized the need to present "our case" and the "American case," and he reviewed successive drafts of reports that the Zionists were submitting to the Commission. The goal, Brandeis instructed, was "to bring American influence to bear in every way possible." 95

Although defeat of the threatened suspension was a resounding victory, the turmoil, uncertainty, and violence in Palestine continued. Pleas for

93. "Report of His Majesty's Government," para. 67; and LDBP-L, reel 104: Wise to Brandeis, October 6, 1936, enclosing "Report of a Visit of Dr. Stephen S. Wise to President Franklin D. Roosevelt at Hyde Park," dated October 5, 1936, 2. Brandeis had made the suggestion of an aide memoire almost immediately after learning of Wise's September 1 meeting with Hull. Brandeis to Wise, September 4, 1936, Letters, 5:576. See LDBP-L, reel 104: Wise to Brandeis, October 6, 1936.

94. "Report of His Majesty's Government," para. 71. Bending to intense Arab counterpressures, Britain compromised and established smaller quotas, estimating that "the total [of Jewish immigration] for the six months from October 1936 will be substantially below that for the preceding six months." Ibid., para. 71. Given various exceptions in the immigration system, however, the United States State Department concluded that "immigration into Palestine has not been reduced to anywhere near the extent which is indicated" by the formal quota numbers. Paul H. Alling to assistant secretary of state, November 6, 1936, Foreign Relations, 1936, 454.

95. LDBP-L, reel 103: Brandeis to Julian Mack, October 11, 1936; LDBP-L, reel 104: Brandeis to Julius Simon, July 31, 1936; Brandeis to Wise, November 1, 1936; and Robert Szold to Brandeis, November 25, 1936. See LDBP-L, reel 104: Wise to Israel Ben Brodie, July 8, 1936; Brandeis to Julian W. Mack, October 17, 1936; Brandeis to Wise, November 1, 1936; Robert Szold to Brandeis, Novembr 17, 1936; Mrs. Edward Jacobs to Brandeis, December 11, 1936 ("Hadassah's 'case"); and Maurice B. Hexter to Brandeis, December 18, 1936; Brandeis to Szold, September 5, 1936, Letters 5;577-81. 
assistance from the Jewish Agency in Palestine poured in, and Brandeis continued to try to hold Zionist and non-Zionist Jews together in a united front. Deploring the continuing violence against Palestinian Jews, he confessed that "all of us must expect intensified anti-Semitic attacks as long as Hitler is in power." 96 Between early October and mid-December, he gave Ben-Gurion at least $\$ 40,000$ for arms. ${ }^{97}$

Brandeis's intense Zionist efforts in the latter half of 1936 coincided with both Roosevelt's re-election campaign and the period when the general political relationship between the two men was at its closest. In the 20 months between Humphrey's Executor v. United States and the invalidation of the National Recovery Act (NRA) in May 1935 and Roosevelt's announcement of his Court-packing plan in February 1937, Brandeis's enthusiasm for the president and the New Deal was at its peak. Understandably, he reacted with deep satisfaction at Roosevelt's huge re-election triumph on November 3. His response, recorded the next day, was revealing. "F.D.," Brandeis wrote Frankfurter, "should be of much help re Palestine."98

Only 16 days after Roosevelt's re-election, the Court heard oral arguments in Curtiss-Wright, and one month later it handed down its decision. It seems hard to believe that Brandeis's view of Sutherland's opinion and its executive power language was not colored by his relationship with Roosevelt at the time. Brandeis was profoundly grateful for the president's response to the Palestine immigration crisis, extremely anxious over the undetermined future of the endangered Zionist cause, and deeply worried about the conclusions and recommendations the Royal Commission would offer. Above all, he was acutely aware of the crucial importance of Roosevelt's independence and discretion in conducting American foreign policy. That power seemed the key to the Zionist future. The independent constitutional power of the president in foreign affairs could hardly have

96. LDBP-L, reel 103: Wise to Brandeis, April 23, 1936; LDBP-L, reel 104: E. Kaplan to Wise, November 18, 1936; Robert Szold to Brandeis, December 12, 1936; Brandeis to Wise, September 24, 1936; Mack to Brandeis, Oct. 13, 1936; Brandeis to Mack, November 2, 1936; and memo, "Conference with Mr. Warburg and Associates," (undated); Brandeis to Frankfurter, August 20, 1936, "Half Brother", 584; Brandeis to Robert Szold, September 5, 1936, Letters, 5:577-81; and Brandeis to Frankfurter, November 5, 1936, "Half Brother", 589.

97. Louis J. Paper, Brandeis: An Intimate Biography of One of America's Truly Great Supreme Court Justices (Englewood Cliffs, NJ: Prentice-Hall, Inc., 1983), 387; Urofsky, Louis D. Brandeis, 738; LDBP-L, reel 104: Robert Szold to Wise, October 14, 1936; Szold to Brandeis, November 4, 1936; Szold (?) to Wise, November 4, 1936; and Szold to Brandeis, December 12, 1936; Brandeis to Szold, October 5, 1936, Letters, 5:582.

98. Murphy, Brandeis/Frankfurter Connection, 158-59, 178; Strum, Brandeis, 393; Urofsky, Louis D. Brandeis, 709-13; and Brandeis to Frankfurter, November 4, 1936, "Half Brother", 589. 
seemed more desirable and benevolent to Brandeis at any point in his entire life than at the exact moment when he turned his attention to Curtiss-Wright. ${ }^{99}$

In that context, Brandeis would most probably have found Hughes's position on executive foreign affairs power convincing. He would have listened carefully to the chief justice's views on foreign affairs issues in any event, for he recognized the importance of his broad experience in the area. Hughes, Brandeis believed, had been an outstanding secretary of state who had "done an admirable job." More to the point, unlike their positions on some domestic issues, their views on foreign policy, especially the threat of Nazism and war, overlapped substantially. ${ }^{100}$

Hughes and Brandeis, moreover, had long worked well together, and their personal character and judicial manner meant that disagreements "were always disposed of in a friendly fashion." Brandeis admired the progressive values that Hughes had shown as governor and associate justice, considered him an exceptional administrator, and admired his mastery of the facts in introducing cases in conference. That last quality, one that the two men valued and shared in the highest degree, fortified their mutual respect. In retirement, Brandeis told friends that Hughes had been the finest chief justice he had known. ${ }^{101}$

99. Brandeis may have been more than ready to support the delegation at issue. In conference, the justices apparently addressed two additional issues. One was whether the banned property at issue (fifteen machine guns) was actually sold in the United States, a condition necessary to make the sale unlawful. Brandeis wrote in his docket book "property considered here," suggesting that he supported that position in the discussion. The other, and seemingly more telling, issue was the significance of the fact that the president had terminated the prohibition against arms sales on October 28, 1935, but that the indictment had not been authorized until January, 1936. Powell, "Story of Curtiss-Wright," 205, 207. Butler apparently thought that "all questions as to validity is [up or "op[en]"?]-termination is qu[estion] of validity." Brandeis apparently supported the contrary position, writing "whether terminated not a question of validity." CSC, Justice Brandeis, United States v. Curtiss-Wright Export Corp., docket book (1936); and Justice Butler, United States v. Curtiss-Wright Export Corp., docket book (1936).

100. Brandeis to Frankfurter, November 13, 1921, Letters, 5:33. For a similar statement about Hughes as secretary of state, see Brandeis to Alfred Brandeis, November 13, 1921, Letters, 5:32. When Hughes left office, his stewardship of the State Department was widely praised. Glad, Charles Evans Hughes, 149-51. Brandeis may also have seen Hughes as relatively sympathetic to Jewish issues. See above, note 46, and Brandeis's view of Frank v. Mangum, 237 U.S. 309, 345 (1915) (Holmes and Hughes, JJ., dissenting) in Brandeis to Roscoe Pound, November 27, 1914; Brandeis to Alfred Brandeis, December 12, 1914; and Brandeis to George Sutherland, November 6, 1915, Letters, 3:373, 383, 632.

101. Pusey, Charles Evans Hughes, 2:654, 669, 785; and Urofsky, Louis D. Brandeis, 675 ; "My admiration of the C.J.'s performances at conference continues unabated," Brandeis declàred. Brandeis to Frankfurter, May 2, 1931, "Half Brother", 457. For a similar statement, see Brandeis to Frankfurter, May 30, 1930, ibid., 431. By 1936, Brandeis may 
The two cooperated closely and with great sensitivity in handling several particularly delicate Court matters. When Holmes began fading badly in late 1931, the two agreed to share responsibility for what both regarded as "a highly disagreeable duty." Hughes visited Holmes and advised him that the time had come for him to retire, and shortly thereafter Brandeis appeared by prearrangement to console Holmes as much as possible. Then, when Roosevelt announced his Court-packing plan in February of 1937, Hughes and Brandeis worked together discreetly to deliver a major blow against the proposal. Finally, in 1937 when Brandeis grew concerned with his own aging, he turned to Hughes for counsel. He began periodically consulting the chief justice about the possibly declining quality of his work, and Hughes repeatedly urged him to stay. Even when Brandeis made the decision to retire in early 1939, Hughes asked him to reconsider. ${ }^{102}$

Therefore, Brandeis would have trusted Hughes's judgment on an issue of foreign affairs law, and his conviction that Roosevelt's independence in the area was crucial to the struggle against Hitler and the cause of Zionism would likely have made Hughes's position compelling. The fact that their substantive foreign policy views overlapped substantially would have confirmed for Brandeis the wisdom of endorsing Hughes's position, while their cordial working relationship and mutual admiration would have made it easy for him to follow the chief justice's lead.

\section{The Other Justices}

Of the remaining justices, the readiest vote for Sutherland's opinion surely came from Cardozo. He would have entertained no doubt that the congressional resolution was constitutional because he was willing to stretch the delegation doctrine to its outermost limit. The only justice to dissent in Panama Refining Co. v. Ryan, Cardozo had searched diligently for an adequate guiding principle before generously locating it in the statute's general statement of purpose. Even in Schechter, in which he agreed that the

also have come to feel a certain sympathy for Hughes as chief justice of a deeply divided Court. Whereas Stone criticized Hughes sharply, Brandeis-similarly frustrated with some of Hughes's actions as chief justice-nonetheless reacted with more sensitivity. Hughes "has no control over the Court," he informed Frankfurter, and he "is deeply unhappy." Shesol, Supreme Power, 214.

102. Hughes, Autobiographical Notes, 298-99 (quotes at 299); Paper, Brandeis, 327; G. Edward White, Justice Oliver Wendell Holmes: Law and the Inner Self (New York: Oxford University Press, 1993), 466-67; Shesol, Supreme Power, 392-401; and Urofsky, Louis D. Brandeis, 715-18, 748. 
delegation had gone too far, he refused to join the majority's opinion. Concurring separately, he declared the delegation wanting for both its wholesale lack of standards and its all-encompassing sweep: the fact that it conferred essentially unlimited power over the whole national economy. ${ }^{103}$ The delegation at issue in Curtiss-Wright was readily distinguishable on both grounds. It provided a somewhat more specific standard and had a far more narrowly circumscribed scope.

Notwithstanding his generous view of delegation, however, Cardozo might have hesitated over the broad executive power dicta in Sutherland's opinion. Like Brandeis, he also sought to avoid unnecessary constitutional language, and he favored opinions with narrower and factually specific reasoning. ${ }^{104}$ In accepting Curtiss-Wright's executive power language, however, he ignored those judicial guidelines, and he likely did so because in the context of 1936 he agreed on the immediate need for a strong and independent executive foreign affairs power as a matter of substantive policy. Cardozo had been worrying about American involvement in a new world war since at least 1932, and the subsequent triumph of Nazism compounded his fears and fired his anger. Cardozo nourished a strong sense of Jewish identity, and he reacted immediately and viscerally against Hitler and Nazism. "The Hitler business is humiliating," he exclaimed only days after the German leader came to power. Readily condemning "the Hitler horrors" and the "whole shameful business" of Nazism, he grew increasingly distressed over the trend of events. By 1936, he was writing dejectedly that the "world is pretty troubled these days" and complaining that he met few people who were "fired with a kindred zeal" and "aflame upon the subject" of Nazism as he was. "We need another Garrison," he protested, "who will cry out unceasingly until all the world shall hear." 105

103. Panama Refining, 433 (1935) (Cardozo, J., dissenting); and Schechter Poultry, 551, 553-54 (1935) (Cardozo, J., concurring, joined by Stone, J.). See Kaufman, Cardozo, 512. Cardozo had taken a similarly generous position on delegation of power at the state level while he served on the New York Court of Appeals. Ibid., 369-71.

104. Kaufman, Cardozo, 524, 560-61. See, for example, Hamilton v. Regents of the University of California, 293 U.S. 245, 265 (1934) (Cardozo, J., concurring, joined by Brandeis and Stone, JJ.).

105. Kaufman, Cardozo, 157, 175-77, 487-89; Richard Polenberg, The World of Benjamin Cardozo: Personal Values and the Judicial Process (Cambridge, MA: Harvard University Press, 1997), 176-78, 182-83; Benjamin N. Cardozo Papers, Columbia University (hereafter BNCP), box 12, "Letters," Vol. 2, Cardozo to Joseph M. Paley, Mar. 29, 1933; BNCP, box 9, Cardozo to Wise, April 29, 1933, and October 31, 1933; and BNCP, box 1B, Cardozo to Rupert L. Joseph, August 11, 1936. Although Cardozo strove to separate his personal feelings about Nazism from his judicial duty, (Kaufman, 
Therefore, Cardozo had every reason to join Sutherland's opinion, notwithstanding its unnecessary language. Doctrinally, he had no problem with the delegation issue. Practically, he hated Hitlerism, feared a coming war, and supported a strongly anti-Nazi foreign policy. Politically, he trusted Roosevelt and his leadership, and was generally more sympathetic to the president and the New Deal than was Brandeis. ${ }^{106}$ Privately, he heard no contrary arguments from his normal allies. Stone was absent, while Brandeis may have encouraged him to join Sutherland's opinion.

Beyond their formal opinions, Van Devanter, Butler, and Roberts left behind the scantiest evidence of their work on the Court. Their decision to join Sutherland's opinion, however, seemed readily understandable and likely based on the same considerations that moved Hughes and Sutherland, if not necessarily Brandeis and Cardozo. First, all three were predisposed to accept strong national foreign affairs powers and a substantial amount of executive discretion in the area. During and after World War I, Van Devanter joined the Court's decisions upholding wide-ranging exercises of the war power, ${ }^{107}$ and Butler and Roberts subsequently did the same. All joined Trading-with-the-Enemy-Act cases that upheld the power of Congress to authorize uncompensated seizures of enemy and other "foreign" property as well as its power to delegate ample and flexible authority to the executive to make the power effective. ${ }^{108}$ In United States v. Chemical Foundation, Inc., for example, Butler declared congressional

Cardozo, 487-88) Curtiss-Wright unavoidably implicated his views about Roosevelt, foreign policy, and the likelihood of a new world war.

106. Kaufman, Cardozo, 487, 513; and Polenberg, World of Benjamin Cardozo, 195. Although never as active or dedicated as Brandeis, Cardozo also accepted Zionism and supported Jewish settlement in Palestine. Kaufman, Cardozo, 175-77, 487-88; and Polenberg, World of Benjamin Cardozo, 176-77. Therefore, Roosevelt's actions in the Palestinian crisis may also have helped induce him to accept Curtiss-Wright's executive power language.

107. Selective Draft Law Cases, 245 U.S. 146 (1919) (upholding draft); Hamilton v. Kentucky Distilleries Co., 251 (1919) (upholding wartime Prohibition); Northern Pacific Railway Co. v. North Dakota, 250 U.S. 135 (1919) (upholding war power as authority for federal takeover of the railroads); and United States v. Cohen Grocery, 255 U.S. 109 (1921) (upholding federal price controls over food and fuels).

108. Woodson v. Deutsche Gold und Silber Scheideanstalt Vormals Roessler, 292 U.S. 449 (1934) (per Butler, with Sutherland, Van Devanter, and Roberts joining); Stoehr v. Wallace, 255 U.S. 239 (1921) (Van Devanter; Butler, Sutherland; Roberts not yet on Court); United States v. Chemical Foundation, 272 U.S. 1 (1926) (per Butler, with Van Devanter joining; Sutherland not participating and Roberts not yet on the Court); and Cummings v. Deutsche Bank und Discontogesellschaft, 300 U.S. 115 (1937) (per Butler, with Sutherland and Van Devanter joining; Roberts not participating). See Samuel Anatole Lourie, "The Trading With the Enemy Act," Michigan Law Review 42 (1943): $221,223$. 
power in the area "untrammeled" and upheld the statute's delegation on the generously expansive, if not almost cavalier, ground that it "went as far as was reasonably practicable under the circumstances."109

Second, Curtiss-Wright's "internal/external" dichotomy apparently satisfied their delegation concerns. Sutherland carefully reached out to them by underscoring its decisive importance. He not only declared it "unnecessary to determine" whether a similar delegation would be unconstitutional if the case involved "internal affairs," but went further, announcing that the Court was "assuming (but not deciding) that the challenged delegation, if it were confined to internal affairs, would be invalid." Indeed, he repeated the point, declaring that "within the international field," Congress "must often accord to the President a degree of discretion and freedom from statutory restriction which would not be admissible were domestic affairs alone involved." 110

Third, none of the three had notable experience in foreign affairs, and they would have listened to those who did. ${ }^{111}$ For Van Devanter and Butler, Sutherland would have been a familiar and readily acceptable guide, and Hughes's advocacy would have fortified their natural inclination to side with Sutherland. For Roberts, Hughes would have been particularly influential. The chief justice had taken Roberts under his wing from their early days on the Court, and Roberts later described Hughes as being like a father to him. He believed that Hughes "dominated the court by reason of the power and keenness of his intellect" and by the force of his "towering personality." Although he did not, always agree with Hughes, he would have listened carefully to the chief justice's arguments on an issue of foreign affairs law and in Curtiss-Wright would almost certainly have accepted his views. ${ }^{12}$

109. Chemical Foundation, 11, 12. Butler suggested a similar view in Highland v. Russell Car \& Snow Plow Co., 279 U.S. 253, 262 (1929) (per Butler, joined by Van Devanter and Sutherland; Roberts not yet on the Court) (upholding sweeping delegation under the war power).

110. Curtiss-Wright, 315, 320. Roberts may not have found this consideration critical, but Van Devanter and Butler apparently did. See above, note 19. Sutherland may also have sought to increase the appeal of his opinion to Butler by echoing a point that Butler had made in one of his Trading-with-the-Enemy Act opinions. Compare Chemical Foundation, 12 with Curtiss-Wright, 320. Butler may have been the justice most in need of persuasion on the executive power language. See note 120 below.

111. There was one minor exception. In 1932, Roberts served as umpire on a mixed claims commission to determine German liability for damages occurring on American soil during the war. John J. McCloy, "Owen J. Roberts' Extra Curiam Activities," University of Pennsylvania Law Review 104 (1955): 351.

112. Hughes, Autobiographical Notes, 298; Danelski and Tulchin, "Editors' Introduction," in Hughes, Autobiographical Notes, xx; Carter and Adams, "Justice Owen J. Roberts," 385, 386. Roberts did sometimes disagree with Hughes. Pusey, Charles Evans Hughes, 2:706. 
Dissenting alone, McReynolds did not even bother to write an opinion, but his disagreement seemed independent of any significant concern over foreign policy. ${ }^{13} \mathrm{He}$ held a narrow conception of the delegation doctrine and, far more salient, a particularly narrow conception of executive power. Further, on both political and personal grounds, he would have been loath to acknowledge a special or novel executive power of any type while Franklin Roosevelt was president. He abhorred Roosevelt's domestic policies and was his harshest and angriest critic on the Court. Perhaps most important, McReynolds was a man of intense emotions and extreme personal antipathies, and he despised Roosevelt. No matter what might happen, he had vowed, he would never resign from the Court "as long as that crippled son-of-a-bitch is in the White House." 114 Therefore, his refusal to join an opinion asserting the president's "plenary and exclusive" power was hardly surprising. Doctrinal, political, and personal grounds explained his decision, and those grounds had little or nothing to do with the foreign policy issues that wracked the 1930s.

\section{Confirmation from Opposition: The Return of Stone}

Although Stone had been absent because of serious illness when the Court considered Curtiss-Wright ${ }^{115}$ on his return he quickly made his opposition clear. "I had no part" in the case, he hastened to inform Edward

113. According to his law clerk, McReynolds intended to write a dissent, but may have decided, instead, to go duck hunting. David J. Garrow and Dennis J. Hutchison, eds., The Forgotten Memoir of John Know: A Year in the Life of a Supreme Court Clerk in FDR's Washington (Chicago: University of Chicago Press, 2002), 157. It is possible that McReynold's dissent may, in some part, have reflected his disagreement with the majority over the wisdom of an anti-Nazi foreign policy. McReynolds was "a virulent anti-Semite," Urofsky, Louis D. Brandeis, 388, who would hardly have scorned Nazism because of its hostility toward Jews. See Urofsky, Louis D. Brandeis, 479, 749; and Kaufman, Cardozo, 479-80.

114. H. P. Hood \& Sons v. United States, 307 U.S. 588, 603 (1939) (Roberts, J., dissenting, joined by McReynolds and Butler, JJ.) (narrow delegation); Myers v. United States, 272 U.S. 52, 178 (1926) (McReynolds, J., dissenting) (narrow executive power); and Shesol, Supreme Power, 6. On McReynolds's character, see Alexander M. Bickel and Benno C. Schmidt, Jr., The Judiciary and Responsible Government, 1910-1921 (New York: The Macmillan Company, 1984), 352-57; and Freund, "Charles Evans Hughes as Chief Justice," 12.

115. On October 12, 1936, Stone was struck with an attack of bacillary dysentery so severe that for 6 weeks his life was in danger, and for another 3 weeks he remained confined to his home. On December 20, when the worst was over, he and his wife left Washingtonthe justice in a wheelchair-for a month of rest and recuperation in Sea Island, Georgia. He did not retum to the bench until February 1, 1937. Mason, Harlan Fisk Stone, 536-37. 
M. Borchard, a professor at Yale Law School. "I should be glad to be disassociated" from it. ${ }^{116}$ At his first opportunity, in fact, Stone did disassociate himself. In early March of 1937, only one month after his return to the bench, the Court heard argument in United States v. Belmont, and Hughes assigned Sutherland to write for the Court. Relying on Curtiss-Wright, Sutherland once again went beyond the questions presented and produced another sweeping opinion that further extended the principle of executive independence and discretion in foreign affairs. ${ }^{117}$ Stone refused to join and concurred in the result only, avoiding the broad constitutional claims Sutherland advanced and relying on narrow and technical grounds. ${ }^{18}$

Stone's rejection of Curtiss-Wright was not only immediate but intense, and his hostile reaction was rooted in his heartfelt judgments on foreign policy. ${ }^{119}$ Whereas in the circumstances Hughes, Sutherland, Brandeis, and Cardozo-and likely some or all of the other majority justices as well ${ }^{120}$ - agreed on the desirability of executive discretion in foreign affairs

116. HFSP, box 6, Stone to Borchard, May 13, 1937. For similar statements, see HFSP, box 6, Stone to Borchard, February 11, 1942.

117. Belmont upheld the authority of the executive to make binding agreements with foreign countries without the consent of Congress or the Senate. Hughes had exercised that power when he was secretary of state, and, therefore, Belmont may also have been in some part the product of Hughes's specific constitutional views. See text preceding note 35. In his 1919 book, Sutherland accepted the principle that the president could sign some international agreements without Senate approval, though he argued that such agreements were limited to relatively minor and short-term matters that did not involve issues of basic policy. Sutherland, Constitutional Power, 120-21.

118. United States v. Belmont, 301 U.S. 324 (1937) (Sutherland, J.), 333 (Stone concurring). Brandeis and Cardozo joined Stone's concurrence, but they did so on grounds unrelated to Curtiss-Wright. Belmont raised a substantial question of state lawmaking authority that was entirely absent from the earlier case, the power of New York State to apply its own law to a bank account located in the state held by a Russian corporation and claimed as an expropriated asset by the government of the Soviet Union. Cardozo explicitly told Stone that he joined the Belmont concurrence because he disagreed with the majority's substantive statements about the scope of federal and state lawmaking authority in such a situation, a federalism concem not relevant in Curtiss-Wright. HFSP, box 74, memo from Cardozo to Stone, April 21, 1937. Brandeis would almost certainly have agreed with Cardozo's concern about state lawmaking authority and with his reasoning about Belmont.

119. Stone's disagreement with Curtiss-Wright almost certainly did not involve any doubts about the constitutionality of the congressional delegation. He had joined Cardozo's separate concurrence in Schechter, and under Cardozo's reasoning the delegation in Curtiss-Wright would easily have passed constitutional muster. See above, text at note 103 .

120. Van Devanter wrote privately on the day that Curtiss-Wright was decided, "the troubles of today certainly have a very serious side" and suggested "we shall have to remember the old minstrel's ejaculation "cheer up, old fellow, the worst is yet to come." WVDP, Box 19, letterbook 53, Van Devanter to Dennis T. Flynn, December 21, 1936. Although he did not identify the particular "troubles of today" that he had in mind, he did in the following weeks special order two recently published books, one by a militant internationalist who 
and a vigorous anti-Nazi foreign policy, Stone feared the former and opposed the latter. Embracing neutrality and noninvolvement, he scorned internationalist principles of collective security and fervently rejected the argument that discretionary arms embargos would deter aggression and prevent war. When Congress was considering the 1936 Neutrality Act, he expressed his admiration for Senator Hiram Johnson's adamant opposition to any grant of executive descretion and insisted that such discretion would do nothing but drag the nation "into trouble." The "present proposal for neutrality to be operated in the discretion of the President," he told John

insisted that war was coming, and the other by a staunch defender of the League of Nations, the World Court, and Wilson's decision to enter World War I. WVDP, Box 19, letterbook 53, John T. McHale (Van Devanter's secretary) to The Macmillan Company, December 14, 1936 (ordering Hamilton Fish Armstrong, We or They: Two Worlds in Conflict); Van Devanter to Council on Foreign Relations, January 25, 1937 (ordering Newton D. Baker, Why We Went to War). The Armstrong book, for example, stated that "it takes only one to make a war. ... The decision between peace and war, then, does not really rest with the pacifically inclined, with those who are willing to make great concessions to secure peace. It rests with those who wait only for circumstances in which they can make war successfully." Armstrong, We or They, 34. It concluded: "Lenin was right, Mussolini and Hitler are right: between the two doctrines [democracy and dictatorship] there is no compromise. Our society or theirs. We or they." Ibid., 103. Baker announced that his book "will not appeal to those whose thinking starts from the pacifist or communistic point of view," Baker, Why We Went to War,158. Van Devanter was, therefore, at a minimum, seriously concerned about the foreign dangers the nation faced. For his part, Butler may have been the justice most hesitant about accepting Curtiss-Wright's executive power language. In both an earlier and a later case in the 1936 term he seemed to harbor a concern that the exercise of executive foreign affairs powers might need the authorization of a statute or treaty. In Belmont, which upheld the power of the executive to make binding agreements with foreign nations without securing the approval of Congress or the Senate, Butler did not vote in the initial conference, but simply passed. CSC, Justice Butler, Valentine v. United States, docket book (1936); and Justice Butler, United States v. Belmont, docket book (1936). Subsequently, he agreed to join Sutherland's majority opinion in Belmont. In Curtiss-Wright, at least, and perhaps in Belmont as well, Sutherland's argument about the special nature of the nation's "external" power was apparently decisive. See note 19 above. Further, if any of the majority justices doubted the desirability of an anti-Nazi foreign policy, it would likely also have been Butler. The son of Irish immigrants, he may have harbored some resentments against England, and as a devout Catholic, he may have harbored some ambivalence about opposing Nazi Germany at a time when Hitler appeared to be a bulwark against the spread of Soviet communism. Conversely, however, any such attitudes might have been counterbalanced by Butler's general view of national foreign affairs powers and by the fact that he was an intense believer in the virtues of patriotism and the moral necessity for complete loyalty to the nation. See notes 108-9 and accompanying text; David J. Danelski, "Pierce Butler," in The Supreme Court Justices: A Biographical Dictionary, ed., Melvin I. Urofsky (New York: Garland Publishing Inc., 1994), 81-82. See, generally, David Bruner, "Pierce Butler," in The Justices of the Supreme Court, 1789-1978, 5 vols., eds. Leon Friedman and Fred L. Israel (New York: Chelsea House, 1997), 3:1081-90. 
Bassett Moore, a professor of international law at Columbia University, showed that "nothing is too ridiculous for a large number of our people to swallow if it is properly sugar-coated with 'Peace'." Stone's hostility to executive discretion was so intense that he wrote to Moore only weeks later to reiterate "how utterly unneutral is a discretionary "neutrality to be exercised in the discretion of the President', Stone's fear of Roosevelt's foreign policy only intensified over the years. In early 1938, he wamed against "an inclination on the part of people in high place to stir up wartime animosity," and harbored increasingly grave forebodings. "I have much to fear that there is a disposition in high quarters to take a hand in European affairs," he wrote, and "I fear that disposition more than I can say." 121

Even more arresting than Stone's fervent neutralist convictions and his acute fear of Roosevelt's foreign policy was his noticeably restrained attitude toward Hitler and Nazism. Although he expressed clear disapproval of Nazism and its actions, ${ }^{122}$ he opposed anti-Nazi foreign policy initiatives. Such efforts, he believed, were unwise and dangerous. In 1936, he informed Frankfurter, to the latter's undoubted chagrin and anger, "I know quite a number of Germans in Washington and have continued friendly relations with them." 123 More revealing, after Kristallnacht in 1938, when Secretary of the Interior Harold L. Ickes, Senator William King of Utah, and President Roosevelt himself all condemned the Nazi-inspired violence, Stone protested their statements. It was a "sad

121. Mason, Harlan Fiske Stone, 545; HFSP, box 22, Stone to John Bassett Moore, February 27, 1932; Stone to Moore, January 12, 1936; Stone to Moore, February 4, 1936; Stone to Moore, February 15, 1936; Stone to Moore, January 22, 1938; Stone to Moore, February 25, 1938; and Stone to Moore, May 19, 1938. Stone had a low regard for Hughes's disarmament efforts when the latter was secretary of state, HFSP, box 22, Stone to Moore, November 22, 1932, and he resented Hughes on personal and judicial grounds. Mason, Harlan Fiske Stone, 276-82, 316-17, 346-47, 399-402, 414-16, 789-90; HFSP, box 13, Stone to Frankfurter, February 17, 1936; and HFSP, box 8, Stone to Sterling Carr, April 1 and June 2, 1937. Finally, Stone had two sons, Marshall (born 1903) and Lauson (born 1904), who were in their early 30s in 1936. Mason, Harlan Fiske Stone, 79. It seems possible that his views on war and foreign policy may have been influenced by his concern for their future safety.

122. Felix Frankfurter Papers, Harvard Law School (hereafter FFP-H), reel 64: Stone to Frankfurter, March, 25, 1936; HFSP, box 22, Stone to Moore, May 7, 1934; HFSP, box 13, Stone to Frankfurter, April 9, 1936; and Mason, Harlan Fiske Stone, 544-47. Stone showed little interest in Jewish affairs in Palestine. HFSP, box 13, Stone to Frankfurter, June 9, 1936.

123. FFP-H, reel 64: Stone to Frankfurter, March 25, 1936. Frankfurter was a dedicated supporter of Roosevelt and a passionate anti-Nazi who scomed appeasement with Hitler. Max Friedman, "Introduction" in Roosevelt \& Frankfurter: Their Correspondence, 19281945 (Boston: Little, Brown \& Company, 1967), 17. 
spectacle," he complained to Moore, to see "three important officers of our Government hurling Billingsgate at the Nazis in the best Nazi style." Indeed, his intensely anti-Roosevelt and noninterventionist convictions led to an extreme judgment. It was the United States, not Nazi Germany, he insisted, that constituted "the biggest menace for the peace of the world just now." 124

Borchard and Moore, Stone's frequent and fervid correspondents, continually stoked his hostility to discretionary arms embargo legislation, fanned his opposition to Wilsonian ideas of collective security, and encouraged his acute suspicion of Roosevelt's foreign policy. ${ }^{125}$ Both were outspoken critics of the administration, who worked closely with isolationists and neutralists in Congress, including Senator Johnson. ${ }^{126}$ The "present administration in Washington," Borchard declared in September 1936, "is as dangerous to this country as was the Wilson administration." The two Democratic presidents shared foreign policy ideals that "naturally lead to confusion and war." 127

When Curtiss-Wright and Belmont were decided, Borchard and Moore immediately condemned both cases. Borchard wrote to Stone to criticize the first decision, and it was in response that Stone heralded his own disapproval. When Belmont was decided, Borchard told Stone that Sutherland's opinion

124. HFSP, box 22, Stone to Moore, December 23, 1938; and Stone to Moore, March 6, 1939. Moore agreed with Stone's reaction to the Kristallnacht episode. HFSP, box 22, Moore to Stone, December 27, 1938. Stone continued to express strong reservations about American foreign policy in a series of letters to Moore. See, for example, HFSP, box 22, Stone to Moore, April 16, 1939, October 24, 1939, and October 26, 1939; and Mason, Harlan Fiske Stone, 545.

125. HFSP, box 22, Moore to Stone, January 16, 1932, January 22, 1932, April 12, 1933, May 5, 1933, and February 4 1935., See Divine, Illusion of Neutrality, 20-22, 43-45, 14648, 177. For Moore's views at the time, see John Bassett Moore, "The Dictatorial Drift," Virginia Law Review 23 (1937): 863-79.

126. Republican Senator Arthur Vandenberg, an isolationist from Michigan, told Borchard that there were "a number of members of the Senate Foreign Relations Committee who have a very definite respect for your viewpoint." Edward M. Borchard Papers, Yale University (hereafter, EMBP), box 12, folder 164, Arthur Vandenberg to Borchard, January 4, 1937.

127. EMBP, box 119, folder 1131, Borchard to Charles C. Taft, September 5, 1936. Borchard had a noticeably mixed, if not actually sympathetic, reaction to Nazism. EMBP, box 8, folder 104, Borchard to Moore, May 23, 1936 ("nobody did more to create [Hitler] than the New York Times and those who adopt its war-making policies"; a Hitler speech was "statesmanlike and sane"); and EMBP, box 37, folder 424, Borchard to F. W. Bitter, December 28, 1936 (defending Hitler's seizure of the Rhineland). A reviewer noted Borchard's "marked sympathy for Germany and Austria and something approaching strong antipathy toward Britain and France." Malcolm Sharp, review of Neutrality for the United States, University of Chicago Law Review 5 (1937): 165. 
was "incoherent," "deplorable," and "dangerous."128 Although Borchard and Moore criticized both opinions on legal grounds, they worried most immediately about their practical policy consequences. After reading Curtiss-Wright, Moore charged angrily that Sutherland "has endeavored in every possible way to enlarge the sphere of executive discretion." 129

Stone, like Borchard and Moore, opposed discretionary arms embargo legislation and the president's increasingly anti-Nazi foreign policy, and like them he immediately rejected Curtiss-Wright. Their shared reaction to the case was rooted in their fervently held belief that Roosevelt's foreign policy was war-provoking folly and that Sutherland's opinion would strengthen the president's political position and might help sway Congress in his favor. "I dare say the Administration will take advantage of Sutherland's opinion in the Curtis-Wright [sic] case," Borchard predicted, "to ask again for the discretionary [arms-embargo] power they were denied last February."130

Their immediate and common rejection of Sutherland's opinion and their shared hostility to Roosevelt's foreign policy gave powerful support to the inference that the majority's contrary embrace of the opinion stemmed from equally clear but wholly opposed foreign policy commitments. Assistant Attorney General Robert H. Jackson, one of Roosevelt's closest advisers, implicitly recognized that likelihood. Sutherland's opinion, he declared happily, was "a Christmas present to the President." 131

\section{Conclusion: A Pragmatic and Time-Bound Decision}

This historical study of Curtiss-Wright suggests several conclusions. The most obvious is that Sutherland did not simply "win the Court" to his

128. HFSP, box 6, Borchard to Stone, May 6, 1937; Borchard to Stone, July 9, 1937; Stone to Borchard, May 13, 1937; Borchard to Stone, May 6, 1937; and Borchard to Stone, July 9, 1937. See Mason, Harlan Fiske Stone, 544-47.

129. John Bassett Moore Papers, Library of Congress (hereafter JBMP), box 70, Moore to Borchard, December 26, 1936. Other observers noted Curtiss-Wright's unusual emphasis on the independent nature of executive power: for example, Comment, Georgetown Law Journal 25 (1937): 740; Julius Goebel, Jr., "Constitutional History and Constitutional Law," Columbia Law Review 38 (1937): 571-73; note, Harvard Law Review 50 (1937): 692; and Stefan A. Riesenfeld, "The Power of Congress and the President in International Relations: Three Recent Supreme Court Decisions," California Law Review 25 (1937): 668-99.

130. JBMP, box 72, Borchard to Moore, January 20, 1937. See JBMP, box 70, Borchard to Moore, December 24, 1936, and Moore to Borchard, December 26, 1936.

131. Robert H. Jackson, The Struggle for Judicial Supremacy: A Study of a Crisis in American Power Politics (New York: Alfred A. Knopf, 1941), 201. 
own earlier views. Although he did use the opinion to embody certain long-held ideas about sovereignty, nationality, and the extra-constitutional nature of foreign affairs power, his contribution was otherwise limited. ${ }^{132}$ Most important, Curtiss-Wright's language about "plenary and exclusive" executive power-the opinion's most distinctive, important, and controversial aspect-advanced a constitutional proposition that differed substantially from anything he had previously articulated. That critical language mirrored Hughes's long-established views, and it was most likely attributable to the chief justice, not to Sutherland. ${ }^{133}$

If Curtiss-Wright was not simply the product of Sutherland's own long-held theory, it was also not simply the product of the Constitution, historical evidence, the ideas of the Founders, or established doctrines and precedents. Equally, it was not the unavoidable product of the foreign policy challenges of the mid-1930s or the consensus product of either Congress or the general public. Rather, shaped by those foreign policy challenges, it was most likely the product of two historically specific internal institutional factors: first, Hughes's leadership and considered constitutional views, and second, a bench composed of a majority of justices who, for reasons that varied somewhat from one to another, reached a rough consensus accepting Hughes's views and did so, in significant part, because they agreed on the necessity of independent executive leadership in foreign affairs, the need for an anti-Nazi foreign policy, and the undesirability of mandatory neutrality laws. It was a consensus among seven individuals, and it embraced conclusions that were widely contested in the larger society and that would remain widely contested for another 5 years. Curtiss-Wright's executive power language, then, was an overt judicial intervention in an extended national policy debate that divided both the

132. The opinion's emphasis on the "national" nature of foreign affairs powers represented a widely accepted view. David M. Golove, "Treaty-Making and the Nation: The Historical Foundations of the Nationalist Conception of the Treaty Power," Michigan Law Review 98 (2000): 1075-316. Its "internal/external" dichotomy, moreover, utilized a line of division commonly employed to mark rough limits in dealing with both national/international and state/federal relations. See, for example, Charles Evans Hughes, Comments, Proceedings of the American Society for International Law 23 (1929): 194-96.

133. Brandeis's docket book suggests that in conference Sutherland relied specifically on the fact that the delegation dealt with "foreign affairs"- a position that, in his mind, should have provided a sufficient basis for the Court to uphold the delegation as an exercise of distinctive "external" and "national" power. If so, that would lend further support to the article's claim that it was likely not Sutherland who initially urged the justices to include additional language declaring that the executive held "plenary and exclusive" power in foreign affairs. CSC, Justice Brandeis, United States v. Curtiss-Wright Export Corp., docket book (1936). See notes 19,43 , and 44 above. 
American people and the legislative and executive branches of the federal government. ${ }^{134}$

In forging that majority consensus, Hughes was probably decisive. Inspired by his executive orientation, constitutional convictions, experience as secretary of state, and acrid memories of congressional willfulness and obstructionism, he was most likely the architect of the seven-justice majority and the source of Sutherland's executive power language. Indeed, it seems that in the 1920s, Hughes had in effect already decided the issue Curtiss-Wright presented. Therefore, the foreign policy challenges of the 1930 s only spurred his determination to officially announce and affirm the underlying constitutional principles that he so strongly embraced.

Whereas Hughes probably influenced all of the majority justices, he may have had his most decisive effect on Cardozo, Sutherland, and Brandeis. ${ }^{135}$ All three respected Hughes and his expertise in foreign affairs, and all three

134. Powell argues that "Curtiss-Wright played no apparent role in the struggle between the administration and its congressional opponents" and that "FDR's foes continued to have the upper hand throughout the rest of the decade." Powell, "Story of Curtiss-Wright," 22526. The latter point is certainly true. Whether the former is equally true may be doubted. Edward A. Corwin, "The War and the Constitution: President and Congress," American Political Science Review 37 (1943): 18-19; and Arthur Schlesinger, Jr., "Congress and the Making of American Foreign Policy," Foreign Affairs 51 (1972): 92. In any event, Powell's observation does not undermine this article's claim that the justices themselves sought to support the president in his battle with Congress and opposed the views of those who advocated isolationism and mandatory arms embargos. Administration spokesmen, moreover, certainly used the case to argue for strong and independent executive foreign affairs power. See, for example, Edward H. Foley, Jr., "Some Aspects of the Constitutional Powers of the President," American Bar Association Journal 27 (1941): 485; and Robert H. Jackson, "Acquisition of Naval and Air Bases in Exchange for Over-Age Destroyers," Opinions of the Attorney General 39 (1940): 486. Similarly, the work of Sarah Cleveland is not inconsistent with the article's claim about the origins of Curtiss-Wright's executive power language. Examining the "inherent" power background of Curtiss-Wright, she concluded that "Sutherland's theory was distinctly not the product of the pre-World War II pressures that surrounded the decision in Curtiss-Wright." Cleveland, "Powers Inherent in Sovereignty," 277 (emphasis in original). That conclusion, however, referred solely to the "sovereignty" principles that Sutherland invoked in the early parts of Curtiss-Wright and that were drawn from the late nineteenth century "inherent" power doctrine. Her conclusion did not refer to the subsequent language in Curtiss-Wright that shifted "plenary and exclusive" power from the "nation" and Congress to the executive. On that point, Cleveland agrees with the thesis of this article that the old "inherent" power doctrine-a doctrine of "national" and "congressional" power-did not determine or explain Sutherland's two strikingly new moves in Curtiss-Wright: attributing "plenary and exclusive" powers to the executive and asserting the independence of those powers from Congress. Cleveland declares that "Sutherland's introduction of executive hegemony over foreign relations unquestionably was a radical innovation." Ibid., 273. Accord, Cleveland, "Plenary Power Background," 1155.

135. Hughes surely influenced Roberts, who likely had no particular difficulty to overcome in joining the majority opinion. In addition, almost certainly in combination with 
agreed with the underlying anti-Nazi goals of Roosevelt's foreign policy. In order to accept Curtiss-Wright's language about "plenary and exclusive" executive power, Cardozo needed to set aside his long-tempered preference for narrow and fact-based opinions, whereas Sutherland and Brandeis had to modify their thinking even more substantially. ${ }^{136}$ Sutherland had to alter his earlier views on foreign affairs law and ignore any worry he might have entertained that "plenary and exclusive" foreign affairs power would accrue to a president he so deeply distrusted. Brandeis had to ignore the injunctions of his avoidance canon, qualify his commitment to legislative primacy, and set aside his deep suspicions of executive power. Sutherland was likely influenced by his English birth and sympathies, the disappearance of the galvanizing political issues that had shaped his pre-Court writings, and his growing fear of Nazi Germany and belief that a new war with England was "almost inevitable."137 Brandeis was likely influenced along similar lines by his abhorrence of Nazism and his intense Zionist attachment to ensuring Roosevelt's independence and discretion in conducting American foreign policy. In the circumstances of 1936, all three apparently found Hughes's well-seasoned views sufficient to overcome their varied countervailing concerns.

Regarding the law of the Constitution, this article confirms the common understanding that Curtiss-Wright articulated only an amorphous idea of an independent executive foreign affairs power, and that its language offers no guidance as to either the scope or limits of any such power. ${ }^{138}$ As a matter of doctrinal analysis, it would add only one further point. The decisive

Sutherland, Hughes may have been particularly influential in persuading Butler to join the majority. See notes 19,110 , and 120 above.

136. Hughes may also have compromised. It is doubtful that he accepted Sutherland's claim that the national government held extraconstitutional powers in foreign affairs. Compare Sutherland, Constitutional Power, 54-58, and Curtiss-Wright, 318, with Hughes, "War Powers Under the Constitution." "Except in cases involving matters of high principle, [Hughes] willingly acquiesced in silence rather than expose his dissenting views." Danelski and Tulchin, "Editors' Introduction," in Hughes, Autobiographical Notes, xxvi.

137. GSP, box 3, Sutherland to S. Hughes, March 16, 1936. Sutherland would likely have consoled himself with the belief that Roosevelt would be out of office in 4 years and that his "internal/external" dichotomy would, in any event, insulate executive foreign affairs powers from executive power in domestic matters.

138. As Justice Robert Jackson declared, Sutherland's opinion illustrated "the poverty of really useful and unambiguous authority" on questions involving the scope of whatever "independent" constitutional power the executive possessed. Youngstown Sheet \& Tube Co. v. Sawyer, 343 U.S. 579, 634-35 (1952) (Jackson, J., concurring). For similar views, see Powell, "Story of Curtiss-Wright," 231; and Riesenfeld, "Power of Congress and the President," 669. 
fact about Curtiss-Wright as a legal precedent is that it presented no issue of unilateral executive action and no claim that individual constitutional rights were infringed. Therefore, on truly critical and open constitutional issues, it quite literally has nothing to say.

Beyond that, however, the article adds a new and different claim. It suggests that the justices may have known exactly what they were doing when they adopted their vague executive power language. They may have accepted language that they knew was both vague and unnecessary-and obviously so- because their goal was not to provide clear and detailed doctrinal guidance but to provide institutional and moral support for the national executive in an ominous and deeply troubled time. They may have decided, in other words, to enhance the executive's position in dealing with Congress and to signal that the Court's opposition to administration policies in domestic areas did not mean opposition to its efforts to meet the dangers that threatened from abroad. Curtiss-Wright, then, may most reasonably be construed not as timeless doctrine but as timely pragmatics.

Thus, as an exceptionally practical, context-determined, and doctrinally amorphous decision, Curtiss-Wright provides no useful guidance in construing the proper scope and independence of executive foreign affairs power. Even if the Court's affirmation of independent executive power was timely and wise in 1936, that fact tells us nothing about the timeliness or wisdom of affirming such independent executive power in other times and circumstances. With the benefit of later experiences, knowledge of changed conditions, and concern over new and different foreign affairs challenges, Curtiss-Wright's sweeping assertion of "plenary and exclusive" executive power is subject to searching reconsideration and open to substantially altered interpretations and applications.

Indeed, the fact that Curtiss-Wright is so doctrinally amorphous-and that it nonetheless continues to be cited and debated by lawyers and judges-highlights two historical facts. One is that over the course of two and one quarter centuries the Court has decided precious few cases that establish clear constitutional rules governing the relationship between Congress and the executive in conducting the nation's foreign affairs. The other is that the conduct of American foreign relations has to an overwhelming extent been the consequence not of judicial decisions but of changing foreign challenges, shifting national politics, responsive actions by key members of the executive and legislative branches, and the practical working relationships that developed in various periods between Congress and the executive.

Understanding Curtiss-Wright as a historical phenomenon also underscores the easy pliability of historical sources when deployed to undergird legal propositions. Sutherland's historical argument about the foreign 
affairs power was based on a highly selective use of historical evidence designed to support essentially arbitrary assertions about theoretical abstractions. Subsequent scholarship has for the most part rejected it. ${ }^{139}$ His opinion remains significant, however, because it demonstrates the malleability of such sources in the hands of those who wish to confect historical foundations for their current policy preferences. Indeed, the Court's expedient acceptance of Sutherland's historical argument demonstrates how the press of times and conditions can make the most dubious originalist claims appear serviceable and, at least temporarily, acceptable. ${ }^{140}$

Considering Curtiss-Wright historically also highlights the curious but illuminating way that legal arguments and jurisprudential principles mutate over time. Sutherland justified the independent foreign affairs power of the executive on the basis of international law and its principles of sovereignty and nationality. ${ }^{141}$ In contrast, contemporary advocates of executive power -who often cite Curtiss-Wright - tend to reject international law and its principles as proper sources for constitutional interpretation. ${ }^{142}$ Such a transformation in the grounds of legal argument has little to do with either the constitutional text or authoritative legal sources, but demonstrates, instead, the changes that occur in constitutional reasoning over time, the plasticity of legal concepts and assumptions, and the ultimate shaping power of presentist purposes and reigning ideologies.

In the final analysis, then, insofar as Curtiss-Wright has constitutional significance, it is not as an authoritative precedent capable of providing

139. See, for example, Levitan, "Foreign Relations Power"; Lofgren, "Government from Reflection", ch. 5; C. Perry Patterson, "In Re The United States v. The Curtiss-Wright Corporation," Texas Law Review 22 (1944): 286-308; and Michael D. Ramsey, "The Myth of Extraconstitutional Foreign Affairs Power," William \& Mary Law Review 42 (2000): 379-446.

140. As Alfred H. Kelly pointed out a half century ago, originalism as a method of constitutional interpretation is a particularly useful rhetorical mode when one is seeking to change established law. Alfred H. Kelly, "Clio and the Court: An Illicit Love Affair," Supreme Court Review (1965): 119-58.

141. Curtiss-Wright, 318; and Sutherland, Constitutional Power, 30, 45, 54, 58, 64, 7475, 77, 112, 137, 139, 141-42. See Paschal, Mr. Justice Sutherland, 227; and Cleveland, "Plenary Power Background," 1126-55.

142. Compare, for example, Pasquantino v. United States, 544 U.S. 349, 369 (2005) (Thomas, J., citing Curtiss-Wright for proposition that executive is "sole organ of the federal government in the field of international relations"); Hamdi v. Rumsfeld, 542 U.S. 507, 579, 582 (2004) (Thomas, J., dissenting) (citing Curtiss-Wright for "President's independent authority and need to be free from interference" in foreign affairs); and Webster v. Doe, 486 U.S. 592, 606, 614-15 (Scalia, J., dissenting, quoting Curtiss-Wright for "the very delicate, plenary, and exclusive power of the President" in foreign affairs) with Roper v. Simmons, 543 U.S. 551, 607, 622-28 (2005) (Scalia, J., joined by Thomas, J., dissenting and opposing use of foreign and international law to construe Constitution). 
doctrinal guidance, but as an institutional artifact that illustrates some of the constitutional characteristics of American government. It reveals the power of social context to shape the Court's work, the critical importance of the specific individuals who occupy its bench and the varied policy judgments they make, and the complex possibilities that inhere in the Constitution's structure of divided national powers. It illustrates as well the Court's de facto power to act on essentially pragmatic grounds and to intervene at critical times in national controversies. Curtiss-Wright is thus a doubly troubling precedent, not only proclaiming a sweeping and amorphous de jure power in the executive, but also exemplifying an undefined and discretionary de facto power in the judiciary. 


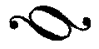

